\title{
Chemical Speciation and Toxicity of Metals Assessed by Three Bioluminescence-Based Assays Using Marine Organisms
}

\author{
Dimitri D. Deheyn, Rizlan Bencheikh-Latmani, Michael I. Latz \\ Marine Biology Research Division, Scripps Institution of Oceanography, \\ University of California, San Diego, La Jolla, California 92093-0202, USA
}

Received 1 November 2003; accepted 14 January 2004

\begin{abstract}
Metal toxicity is a function of the biology of the target organism and the chemical speciation of the metal. The toxicity of 11 metals was assessed with three cell-based bioassays based on marine organisms: the bacterium Photobacterium phosphoreum of the Microtox ${ }^{\circledR}$ bioassay, an environmental strain of $P$. phosphoreum, and photocytes isolated from the brittlestar Ophiopsila californica. Metal speciation was calculated for three commonly used media: $\mathrm{NaCl}$-based Microtox ${ }^{\circledR}$ bioassay medium, artificial seawater glycerol, and artificial seawater. Decreased bioluminescence was considered a proxy for cell toxicity. In all three assays the elements $\mathrm{Cd}$ and $\mathrm{Hg}$ exhibited similar speciation as well as similar toxicity profiles. The element $\mathrm{Cu}$ was toxic in all three assays despite different metal speciation for the $P$. phosphoreum bioassay. The element Ag was toxic to both bacterial strains but not to photocytes despite a similar chemical speciation for all three assays. In general, the Microtox ${ }^{\circledR}$ bioassay was sensitive to all metals (except $\mathrm{Pb}$ ), whereas the photocytes were the least sensitive to the metals. The heightened response of the Microtox ${ }^{\circledR}$ bioassay probably resulted from a combination of the limited complexing power of the medium and the greater sensitivity of the bacterial strain. (C) 2004 Wiley Periodicals, Inc. Environ Toxicol 19: 161-178, 2004.
\end{abstract}

Keywords: bioassay; bioluminescence; chemical speciation; free ion model; HYDRAQL; metal; Microtox ${ }^{\circledR}$; photocyte; toxicity

\section{INTRODUCTION}

The toxicity of a substance is the measure of its incompatibility with normal biological function (Richardson, 1993). Thus, toxicity refers to the adverse impact of a substance on living organisms. It depends on various factors such as the quantity of the substance actually absorbed, the route of

Correspondence to: Dr. Dimitri Deheyn; e-mail: ddeheyn@ucsd.edu

Contract grant sponsor: Belgium-NATO and Belgian-American Educational Foundation (fellowship to D.D.D.); University of California Toxic Substance Research \& Training Program grant (to M.I.L).

Published online in Wiley InterScience (www.interscience.wiley.com). DOI 10.1002/tox.20009 contamination (ingestion, physical contact, accumulation by diffusion, or active cellular pumping), and time exposure. According to the free ion activity model, metal toxicity depends on chemical species formed by the metal and is mainly correlated to free ion concentration; however, that does not necessarily imply that the free metal ion is the only toxic species (Morel and Hering, 1993; Stumm and Morgan, 1995; Campbell and Tessier, 1996). The model merely reflects the ability of free-metal-ion concentration to be taken as an index of reactivity, even though the physiological effects of a metal can also be related to the interaction of its various chemical forms with a variety of cellular ligands. Consequently, determining the toxicity of a given

(C) 2004 Wiley Periodicals, Inc. 
metal requires assessing its chemical speciation in the medium.

Toxicity is dependent on the species involved and the tissue and cells targeted by the toxicant (Richardson, 1993; Clark, 1997; Crosby, 1998). Overall, a toxic effect occurs as the result of a complex balance between the metal's chemical speciation and reactivity and the biology of the organism. Hence, toxicity measurements are usually performed by quantifying the alteration of given biological characteristics (e.g., gene expression, enzyme functionality, fertilization efficiency, growth, behavior) upon exposure to known added concentrations of a specific substance. Change in a biological characteristic is then considered a reflection of an adverse effect of the substance, with the observed changes possibly integrating toxicity that is occurring at various levels of biological complexity, from the genetic to the molecular, cellular, tissue, and organismal levels (Costan et al., 1993; Clark, 1997; Kennish, 1997). Biomonitoring programs use a battery of bioassays to screen such a variety of routes of contamination, involving a diversity of organisms (bacteria, crustaceans, bivalves, fishs), possibly at different stages of development (embryo, larvae, adult). Because of the complexity and cost of such an endeavor, there is strong interest in simplifying toxicity assessment. A common alternative is to use microorganisms genetically engineered to be sensitive to specific contaminants, resulting in assays that are more rapid and less costly (Wood and Gruber, 1996; Hollis et al., 2000; Dizer et al., 2002).

Bioluminescence, the biological production of visible light with an ecological function (Morin, 1983), is commonly used as an bioassay for environmental quality. Most commonly used are luminescent bacteria and dinoflagellates, as well as genetically engineered bacteria that use luminescence reporters (Danilov et al., 1985; Lapota et al., 1993; Kudryasheva et al., 1998; Heimann et al., 2002). The assumption is that decreases in bioluminescence reflect the toxicity of a given condition, because light emission is a measure of the health and metabolism of the luminescent organism.

Light production is the result of a chemical reaction involving the oxidation of a substrate, generally called luciferin, mediated by a protein called luciferase in the presence of an ionic cofactor; the intensity of produced light is proportional to the amount of reagents involved in the chemical reaction. A decrease in the intensity of the light produced therefore indicates alteration of one of the events leading to light production: either the chemical reaction (e.g., configurational inactivity of reagents), the expression of genes coding for the reagents, and/or any physiological control associated with the process.

The present study addressed metal chemical speciation and toxicity in a marine environment with three bioassays based on cellular bioluminescence, using the marine bacterium Photobacterium phosphoreum from the Microtox ${ }^{\circledR}$ bioassay, a wild-type strain of $P$. phosphoreum, and isolated photocytes (light-producing cells) from the brittlestar Ophiopsila californica (Echinodermata). This study addressed the hypothesis that toxicity assessment is different among bioassays because of differences in the physicochemical characteristics of the medium and also because of how biologically susceptible to metal toxicity the particular cells are. In addition, as the study was a test of the free ion activity model, it was expected that the toxicity would be correlated with the free-metal-ion concentrations among bioassays.

\section{MATERIAL AND METHODS}

The metals silver (Ag), aluminum (Al), cadmium (Cd), chromium $(\mathrm{Cr})$, copper $(\mathrm{Cu})$, iron $(\mathrm{Fe})$, mercury $(\mathrm{Hg})$, manganese $(\mathrm{Mn})$, lead $(\mathrm{Pb})$, uranium $(\mathrm{U})$, and zinc $(\mathrm{Zn})$ were assessed for toxicity with three cell-based bioassays, each using in vivo bioluminescence as a reporter of physiological state. The Microtox ${ }^{\circledR}$ bioassay used strain 11177 of the bacterium Photobacterium phosphoreum (synonym: Vibrio fischeri), the $P$. phosphoreum bioassay used a wild-type strain of the same bacterium (Haygood strain 849), and the photocyte bioassay used metazoan luminescent cells (photocytes) isolated from the brittlestar Ophiopsila californica (Echinodermata). For each bioassay the effect of each individual metal on cellular bioluminescence was determined from three independent replicates of the experiment. Depending on metal solubility, 4-6 total metal concentrations were assayed, ranging from $10^{-8}$ to $10^{-3} \mathrm{M}$.

\section{Preparation of Metal Solutions}

Metal stock solutions were freshly prepared by dissolving metal chloride $\left(\mathrm{Cd}^{2+}, \mathrm{Cu}^{2+}, \mathrm{Fe}^{3+}, \mathrm{Hg}^{2+}, \mathrm{Mn}^{2+}, \mathrm{Zn}^{2+}\right)$, sulfate $\left(\mathrm{Al}^{2+}\right)$, or nitrate $\left(\mathrm{Ag}^{+}, \mathrm{Pb}^{2+}\right)$ salt into the medium of interest unless otherwise specified. Stock solutions for $\mathrm{U}$ and $\mathrm{Cr}$ were made from uranyl $\left(\mathrm{UO}_{2}^{2+}\right)$ acetate and sodium chromate $\left(\mathrm{CrO}_{4}^{2-}\right)$, respectively. All metals were obtained from Sigma (St. Louis, MO, USA) and were ACS certified. Stock solutions were at concentrations at which no precipitation was observed over $72 \mathrm{~h}$ at room temperature. The final metal concentration used in experiments was obtained by dilution of the corresponding stock solution.

For each treatment a control was prepared that was identical to the metal stock but without the metal salt. Duration of exposure to the contaminant was the same for all metals and concentrations, ranging from 0 (just before addition of the metal in the medium) to a maximum of 2,9 , or $24 \mathrm{~h}$, depending on the bioassay. If a precipitate was observed in the medium over the experimental period, the assayed concentration was not considered for further investigation. All manipulations were conducted under controlled conditions, avoiding metal and microbial contamination and using disposable polystyrene or high-density polyethylene 
TABLE I. Characteristics of the media used for the three bioassays

\begin{tabular}{|c|c|c|c|c|c|}
\hline \multicolumn{2}{|c|}{$\begin{array}{l}\text { Microtox }{ }^{\circledR} \\
\text { NaCl-based medium } \\
\text { pH: } 6.7 \pm 0.3 ; \mathrm{T}\left({ }^{\circ} \mathrm{C}\right): 15 \pm 0.3\end{array}$} & \multicolumn{2}{|c|}{$\begin{array}{c}\text { P. phosphoreum } \\
\text { ASG-based medium } \\
\mathrm{pH}: 7.4 \pm 0.1 ; \mathrm{T}\left({ }^{\circ} \mathrm{C}\right): 22 \pm 0.2\end{array}$} & \multicolumn{2}{|c|}{$\begin{array}{c}\text { Photocyte } \\
\text { ASW-based medium } \\
\text { pH: } 8.0 \pm 0.1 ; \mathrm{T}\left({ }^{\circ} \mathrm{C}\right): 8 \pm 0.2\end{array}$} \\
\hline ion & {$[\text { ion }]_{\mathrm{T}}(\mathrm{mM})$} & ion & {$[\text { ion }]_{\mathrm{T}}(\mathrm{mM})$} & ion & {$[\text { ion }]_{\mathrm{T}}(\mathrm{mM})$} \\
\hline $\begin{array}{l}\mathrm{Na}^{+} \\
\mathrm{Cl}^{-}\end{array}$ & $\begin{array}{l}342.0 \\
342.0\end{array}$ & $\begin{array}{l}\mathrm{Cl}^{-} \\
\mathrm{K}^{+} \\
\mathrm{Mg}^{2+} \\
\mathrm{SO}_{4}^{2-} \\
\mathrm{Glycerol} \\
\mathrm{NH}_{4}^{+} \\
\mathrm{HEPES}^{\mathrm{a}} \\
\mathrm{Ca}^{2+} \\
\mathrm{HCO}_{3}^{-} \\
\mathrm{Na}^{+} \\
\mathrm{Glycerophosphate}^{\mathrm{FAC}^{\mathrm{b}}}\end{array}$ & $\begin{array}{l}341.05 \\
303.5 \\
48.96 \\
48.96 \\
31.83 \\
18.27 \\
9.77 \\
9.638 \\
1.954 \\
1.954 \\
0.452 \\
0.0322\end{array}$ & $\begin{array}{l}\mathrm{Cl}^{-} \\
\mathrm{Na}^{+} \\
\mathrm{Mg}^{2+} \\
\mathrm{SO}_{4}^{2-} \\
\mathrm{Tris}^{\mathrm{c}} \\
\mathrm{Ca}^{2+} \\
\mathrm{K}^{+}\end{array}$ & $\begin{array}{r}534.4 \\
455.8 \\
52.3 \\
27.7 \\
20.0 \\
9.9 \\
9.6\end{array}$ \\
\hline
\end{tabular}

ASG: artificial seawater glycerol; ASW: artificial seawater.

${ }^{a}$ HEPES: hydroxyethyl piperazine ethane sulfonic acid.

${ }^{b}$ FAC: ferric ammonium citrate with $15 \%-18 \%$ Fe ion.

${ }^{\mathrm{c}}$ Tris: Tris(hydroxymethyl)-aminomethane hydrochloride.

supplies, sterile acid-washed metal-free glassware, and stainless-steel dissecting tools.

\section{Microtox ${ }^{\circledR}$ Bioassay}

The Microtox ${ }^{\circledR}$ Acute Toxicity Test kit, available from AZUR Environmental (Carlsbad, CA, USA), was used according to the Microtox ${ }^{\circledR}$ protocol guidelines for toxicity evaluation (AZUR, 1992). Briefly, lyophilized bacteria $P$. phosphoreum strain NRRL B-11177 were resuspended in 1 $\mathrm{mL}$ of ultrapure water (reconstitution solution; AZUR, Carlsbad, CA, USA). After $10 \mathrm{~min}, 10-\mu \mathrm{L}$ subsamples were added into glass scintillation vials containing $900 \mu \mathrm{L}$ of $2 \%$ $\mathrm{NaCl}$ solution (Diluent Solution, AZUR, Carlsbad, CA, USA), which is the only constituent of the medium for the bioassay (Table I). Metal treatment involved the addition of $100 \mu \mathrm{L}$ of $10.1 \times$ concentrated metal stock solution to the culture. Metal stock solutions were made in $2 \% \mathrm{NaCl}$ solution obtained from the osmotic adjusting solution $(22 \%$ $\mathrm{NaCl}$ solution, AZUR, Carlsbad, CA, USA) diluted with the reconstitution solution. The final solution, with a total volume of $1010 \mu \mathrm{L}$, was incubated without agitation at $15^{\circ} \mathrm{C}$ for up to $2 \mathrm{~h}$. The conditions employed in this experiment are known to be optimal for light to be produced in this bacterium in the absence of metals. Growth is minimal over the 3-h incubation time (Bulich and Isenberg, 1980; Bulich and Huynh, 1995). Bioluminescence was measured after various exposure times $(0,0.25,0.5,1$, and $2 \mathrm{~h})$ using a Quantalum 2000 luminometer (Zefaco Inc., Gaithersburg, MD, USA).

\section{Photobacterium phosphoreum Bioassay}

A wild-type strain of the bacterium Photobacterium phosphoreum was used in the Photobacterium phosphoreum bioassay The $P$. phosphoreum originally were collected from symbiotic bacterial light organs of the salmoniform fish Opisthoproctus soleatus and were kept frozen at $-80^{\circ} \mathrm{C}$ in a $10 \%$ glycerol-seawater complete medium (Nealson, 1978).

For this bioassay, bacteria were cultured at $16^{\circ} \mathrm{C}$ on a solid (agar-amended) artificial seawater glycerol (ASG) medium (Table I) and checked every other day for growth and bioluminescence. An ASG medium was used rather than a rich medium to minimize bacterial growth over the duration of the bioassay and to limit metal complexation (Ramamoorthy and Kushner, 1975; Gellert et al., 1999). The effects of metal treatment on bacterial growth and bioluminescence were assessed using liquid cultures. Bacteria were inoculated from the solid ASG medium into $7 \mathrm{~mL}$ of liquid ASG medium using a sterile loop and were incubated overnight (ca. $10 \mathrm{~h}$ ) under still conditions in glass culture tubes at room temperature (ca. $20^{\circ} \mathrm{C}$ ). The culture was then subsampled, diluted 1000 times into another $7 \mathrm{~mL}$ of ASG medium, and gently agitated on a reciprocal shaker at room temperature. Under these culture conditions, the lag phase lasted about $20 \mathrm{~h}$ after inoculation, followed by a log phase of about $30 \mathrm{~h}$, ending in a stationary phase approximately $55 \mathrm{~h}$ after inoculation. The bioluminescence $\mathrm{cell}^{-1}$ changed during this time, increasing in early log phase, peaking at mid-log phase, and decreasing during late log phase, as 
previously reported (Hastings and Nealson, 1977). Based on this characterization, the experimental window in this study was restricted to a 9-h period (from 24 to $33 \mathrm{~h}$ after inoculation into liquid ASG) to ensure a constant growth rate and an increase in bioluminescence. The metal treatment involved the addition of $100 \mu \mathrm{L}$ of the metal stock solution to the bacterial culture. Stock solutions were made either with the ASG medium (for $\mathrm{Al}, \mathrm{Cd}, \mathrm{Cr}, \mathrm{Mn}$, and $\mathrm{U}$ ) or with ultrapure MilliQ-water (for $\mathrm{Ag}, \mathrm{Cu}, \mathrm{Fe}, \mathrm{Hg}, \mathrm{Pb}$, and $\mathrm{Zn}$ ) to allow complete dissolution. Beginning $24 \mathrm{~h}$ after the liquid ASG inoculation, cell concentration and bioluminescence were measured at times $0,0.5,1,2,3,4,6$, and $9 \mathrm{~h}$ after a 3 -s vortex mixing to allow homogeneous sampling. Cell concentration was determined from optical density (OD) measured with a Spectronic 20 spectrophotometer at 600 nm (Bausch \& Lomb Inc., Madison, WI, USA), whereas glow luminescence was recorded from a $100-\mu \mathrm{L}$ aliquot of the culture using the Quantalum 2000 luminometer. After each experiment the culture was tested for possible microbial contamination by inoculating the content on a solid ASG medium that was checked for growth and bioluminescence on subsequent days. In every case luminescent bacteria, assumed to be $P$. phosphoreum, were the only organisms growing on the plates.

Bacterial bioluminescence depends on cell concentration (Hastings and Nealson, 1977), so light levels measured in this bioassay were expressed per unit cell. The relationship between $\mathrm{OD}_{600}$ and corresponding cell concentration was established during the experimental period. Aliquots from three independent experiments were taken at various times, measured for OD, and processed for cell counting (Smith et al., 1995). Aliquots were fixed with borate-buffered formalin (2\% final concentration) and stained for $10 \mathrm{~min}$ with 1 $\mu \mathrm{g} / \mathrm{mL}$ 4'6-diamidino-2-phenylindole (DAPI). They were then filtered onto $0.2 \mu \mathrm{m}$ of black polycarbonate filters (Nucleopore), mounted on slides with low fluorescence immersion oil (Criterion, Sciences), and examined with an Olympus BH-2 epifluorescence microscope. Individual cells were counted, and the corresponding cell concentration calculated (Porter and Feig, 1980). The linear regression relationship between $\mathrm{OD}_{600}$ and cell abundance, $\mathrm{N}_{\text {cells }}=2184.202+224647.592 \times \mathrm{OD}_{600}$, with $R^{2}=$ $0.934(p<0.0001)$, was used to calculate the number of cells from $\mathrm{OD}_{600}$ measurements.

\section{Photocyte Bioassay}

Photocytes were isolated from the brittlestar Ophiopsila californica (Ophiuroidea, Echinodermata). Brittlestars were collected by SCUBA at night in May and August 2000 at a depth of 7-10 m near the Wrigley Institute for Environmental Studies of the University of Southern California, on Catalina Island, California. Individuals collected from the sandy bottom were immediately placed in fresh circulating seawater aquariums at the Wrigley Center before being transported to the Scripps Institution of Oceanography (La Jolla, CA, USA), where they were kept in circulating seawater aquariums filled with sand from the collection area and fed once a week with plankton broth.

Photocyte isolation was based on the method of (Deheyn et al., 2000a). In summary, 3-5 brittlestars (ca. $5 \mathrm{~g}$ wet weight) were anesthetized for $5 \mathrm{~min}$ in $3.5 \% \mathrm{MgCl}_{2}$ in artificial seawater (Table I); arms were then separated from the disc using surgical scissors and chopped into small fragments with a scalpel blade. Cells were dissociated from arm fragments by enzymatic digestion with three treatments of pronase $\left(35 \mathrm{~min}\right.$ each at $30^{\circ} \mathrm{C}$, followed by ASW rinsing). Dissociated cells from each treatment were pooled together and layered on a Percoll density gradient by ultracentrifugation $\left(30000 \mathrm{~g}, 30 \mathrm{~min}, 4^{\circ} \mathrm{C}\right)$. The concentrated layer of photocytes was then removed from the gradient by pipette and rinsed with $\mathrm{ASW}$ at $4^{\circ} \mathrm{C}$. About $2 \times 10^{8}$ cells $\mathrm{g}^{-1}$ arm tissue was obtained using this procedure. Photocyte light production showed no significant changes in intensity and kinetics for up to $36 \mathrm{~h}$ after isolation. The photocyte bioassay was performed by exposing photocyte suspensions in ASW $(25 \mu \mathrm{L})$ to the same volume of metal stock solution ( $2 \times$ concentrated), for $0,0.5,1,2,3,4,6,9$, and $24 \mathrm{~h}$ (time 0 was always $<1 \mathrm{~h}$ after completion of the photocyte isolation). Light emission was chemically stimulated using $200 \mathrm{mM}$ potassium chloride $(\mathrm{KCl})$ to exhaust total luminescence capacity (Mallefet et al., 1992), and the light emission was recorded for $40 \mathrm{~s}$ using a Lumat 9507 luminometer (EG\&G, Perkin Elmer, Gaithersburg, MD, USA). KClinduced light production is monophasic, consisting of a single flash of bioluminescence characterized by the maximum intensity (Imax) of light production (Deheyn et al., 2000a). Imax values were normalized by the number of photocytes in the $25-\mu \mathrm{L}$ volume, knowing the initial mass of arm tissue used in the isolation process, the number of cells extracted per gram of tissue, and the final volume of ASW-enriched photocyte solution.

\section{Speciation Calculations}

Each bioassay required the use of a specific medium (Table I). Consequently, the chemical characteristics $(\mathrm{pH}$, ionic strength, $I$ ) and metal speciation were different in each bioassay. The speciation of each metal in each medium was calculated using thermodynamic equilibrium constants obtained from a variety of sources (Martell and Smith, 1974; Martell et al., 1993; Morel and Hering, 1993) and the chemical equilibrium program HYDRAQL (Papelis et al., 1988). HYDRAQL uses the Davies activity correction, which is valid for $I \leq 0.5$. The medium used in the photocyte bioassay (ASW) was the only medium for which the ionic strength exceeded 0.5 . It was necessary to invoke the MacInnes convention and the Debye-Huckel limiting law developed by Millero and coworkers (Millero and Schreiber, 1982; Millero and Hawke, 1992). It was not possible to 
apply the MacInnes convention for activity correction to 7 of 183 complexes formed because the required physicochemical data were unavailable for those complexes. However, those complexes did not contribute significantly to the metal speciation $(<0.00001 \%)$ and consequently were ignored. Finally, thermodynamic data for metal complexation by glycerol and glycerolphosphate (both constituents of the medium used in the $P$. phosphoreum bioassay) were unavailable; both constituents were expected to have low complexation with metals (Atay and Robinson, 1999; Atay and Varnali, 2000).

Speciation was calculated for $25^{\circ} \mathrm{C}$ despite the variability in the temperature conditions of the bioassays (Table I). The formation of chemical complexes depends on temperature (Byrne et al., 1988) and can be accurately calculated if enthalpy values are known for the relevant complexes. However, enthalpy values were not available for many complexes. Therefore, bias associated with the absence of temperature correction was estimated for each medium and metal by considering exclusively the most abundant metal complexes for which enthalpy values were available (Martell and Smith, 1974; Byrne et al., 1988; Martell et al., 1993; Stumm and Morgan, 1995). Speciation at $25^{\circ} \mathrm{C}$ and at the temperature of the bioassay was calculated using $\mathrm{HY}$ DRAQL. Overall, complex concentrations at the experimental temperature were lower than that calculated for $25^{\circ} \mathrm{C}$; concentration (mean $\pm 95 \% \mathrm{CI}$ ) was decreased by $13.5 \pm 0.045 \%(n=204)$ for the Microtox ${ }^{\circledR}$ bioassay $\left(15^{\circ} \mathrm{C}\right), 1.4 \pm 0.023 \%(n=237)$ for the P. phosphoreum bioassay $\left(22^{\circ} \mathrm{C}\right)$, and $17.5 \pm 0.043 \%(n=240)$ for the photocyte bioassay $\left(8^{\circ} \mathrm{C}\right)$. Thus, the speciation presented here may overestimate the concentration of some complexes by up to $17.5 \%$.

\section{Statistical Analysis}

The original bioluminescence values or cell culture concentration $\left(\mathrm{OD}_{600}\right)$ were $\log (x+1)$ transformed before statistical analysis, as suggested when homoscedasticity is not fulfilled in a data set (Motulsky, 1995; Zar, 1996). Decreases in bioluminescence or cell concentration were tested for significance using the upper-tailed paired "ratio" $t$-test analysis $\left(H_{0}\right.$ : mean difference $\left.\leq 0\right)$, which is appropriate when the relative difference between treatment and control is a more consistent measure than the absolute value of the treatment (Motulsky, 1995; Zar, 1996). In addition, any occasional increase in bioluminescence or cell concentration (negative $\mathrm{MD}_{t}$ ) was tested using a lower-paired ratio $t$ test $\left(H_{0}\right.$ : mean difference $\left.>0\right)$.

Multifactorial analysis of variance (ANOVA) was performed on primary data of the $P$. phosphoreum bioassay to identify the percentage of variation in bioluminescence because of changes in cell concentration $\left(\mathrm{OD}_{600}\right)$. The percentage was determined by calculating the ratio between the sum of squares associated with the factor and the total sum of squares (all possible factors of variation + residual; Zar, 1996).

The common toxicity indices $\mathrm{EC}_{50}$ and $\mathrm{LT}_{50}$ could not be used in this study because bioluminescence and cell concentration often did not decrease by more than $50 \%$ after metal exposure. Therefore, the parameter MD (mean difference $=$ control - treatment) was used to compare metal effects among bioassays. Thus, positive MD values indicated a decrease in treatment compared to the control, whereas negative MD values described an increase in the treatment compared to the control. $\mathrm{MD}_{t}$ values represented the mean difference calculated at every experimental time point. The test used to determine significance of the $\mathrm{MD}_{t}$ values was based on the upper-tailed paired $t$-test analysis of each metal, and for each concentration the change in $\mathrm{MD}_{t}$ values with time exposure was described using a singlecomponent first-order kinetics exponential model: $\mathrm{MD}_{t}=$ $\mathrm{MD}_{\mathrm{eq}}\left(1-\exp ^{-k^{*} t}\right)$, where $\mathrm{MD}_{t}$ and $\mathrm{MD}_{\mathrm{eq}}$ are the mean differences at time $t(\mathrm{~h})$ and at equilibrium, respectively, and $k$ is the rate constant $\left(\mathrm{h}^{-1}\right)$ (Kuroshima et al., 1993; Slob, 2002). For each metal parameters of the model together with metal chemical speciation were used for comparative analysis of bioassays. All statistical analyses were performed with 0.05 designated as the significance level $(\alpha)$ and using Statview 5.0, Statistica, and SuperAnova 1.11 software (SAS Institute, Inc.).

\section{RESULTS}

For each bioassay, bioluminescence of the control (no metal) sample changed with time. For the Microtox ${ }^{\circledR}$ bioassay, bioluminescence of the control decreased over the 2-h incubation time, with the greatest decrease occurring within the first $0.5 \mathrm{~h}$ (Fig. 1). For the $P$. phosphoreum bioassay, bioluminescence increased steadily concomitantly with cell concentration between the first and ninth hours of the experiment. For the photocyte bioassay, bioluminescence usually increased over the first $6 \mathrm{~h}$ of the experiment, then decreased to the original level. These trends were reproduced for all replicates, but the bioluminescence level varied among replicates (data not shown).

In general, with increasing time and/or concentration of metal exposure, the bioluminescence of the three bioassays decreased compared to the control(Fig. 1). Changes in cell concentration followed the same trend upon metal exposure in the P. phosphoreum bioassay. In this bioassay the growth phase of the culture affected the bioluminescence capacity of the bacteria. Therefore, the percentage of the observed variation in bioluminescence was related to change in cell concentration with time. The exposure concentrations of the metals, calculated using multifactor ANOVA, were Ag, 13.1; Al, 25.9; Cd, 44.2; Cr, 14.6; Cu, 16.5; Fe, 27.1; Hg, 7.2; $\mathrm{Mn}, 32.7 ; \mathrm{Pb}, 25.7$; U, 25.5; and $\mathrm{Zn}, 17.6$. This indi- 

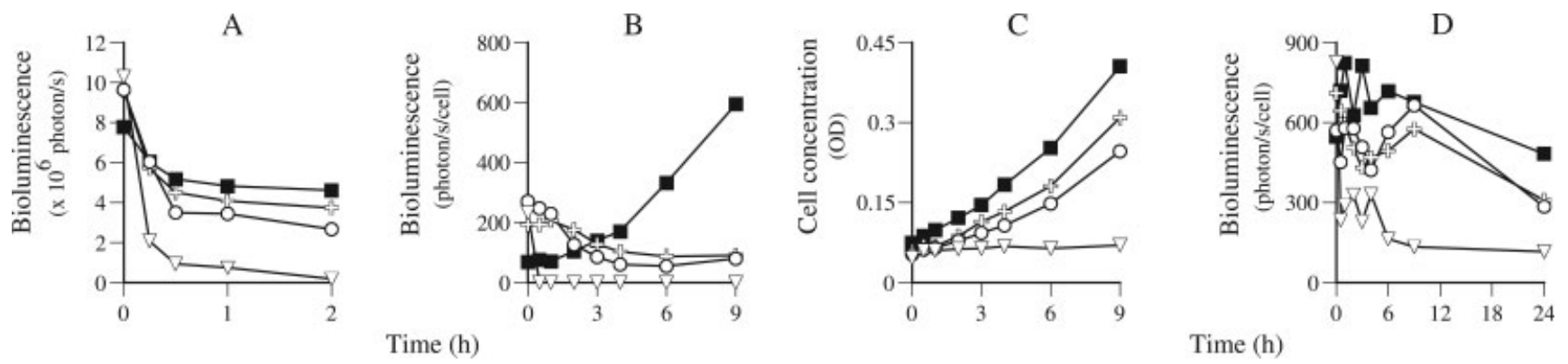

Fig. 1. Effect of $\mathrm{Cd}$ concentration as a function of time on $(\mathrm{A})$ the Microtox ${ }^{\circledR}$ bioassay, $(\mathrm{B}, \mathrm{C})$ the $P$. phoshoreum bioassay, and (D) the photocyte bioassay (symbols legend: $\mathbf{\square}$, control $0 \mathrm{M}$; ↔, $10^{-7} \mathrm{M} ; \bigcirc, 10^{-5} \mathrm{M} ; \triangle, 10^{-3} \mathrm{M}$ ).

cates that for metals like $\mathrm{Hg}$ most of the observed change in bioluminescence was a direct effect of the metal on light production, whereas for metals like $\mathrm{Cd}$, changes in bioluminescence were also resulted from changes in cell concentration.

\section{Modeling Changes in Bioluminescence}

The effect of metal exposure on bioluminescence was modeled for each metal concentration and bioassay using an exponential model of the variation of the $\mathrm{MD}_{t}$ values over time. As shown for $\mathrm{Cd}$ for the three bioassays (Fig. 2), $\mathrm{MD}_{t}$ reached a plateau for the highest and intermediate metal concentrations before the end of the exposure. At the lowest metal concentrations, a plateau was not always reached during the experiment, indicating that at those concentrations, the effects on bioluminescence would be greater for longer exposure times of the bioassay (Fig. 2).

\section{Effect of Exposure Time}

The effect of exposure time was tested for the highest metal concentration considered (Table II). For the Microtox ${ }^{\circledR}$ assays, bioluminescence $\mathrm{MD}_{t}$ values significantly decreased (positive $\mathrm{MD}_{t}$ values) over the entire exposure period (0.25-2 h, as shown for Cd in Fig. 1), except for $\mathrm{Hg}$ and $\mathrm{Mn}$, for which the decrease was significant only after exposures of 1 and $0.5 \mathrm{~h}$, respectively.

For the $P$. phosphoreum bioassay, bioluminescence $\mathrm{MD}_{t}$ values significantly decreased over the entire exposure period (0.5-9 h, as shown for $\mathrm{Cd}$ in Fig. 1) for $\mathrm{Ag}, \mathrm{Cd}, \mathrm{Cu}$, and $\mathrm{Hg}$. A similar effect was observed for $\mathrm{Zn}$, but the decrease was not always significant (Table II). Bioluminescence $\mathrm{MD}_{t}$ values did not change significantly on exposure to $\mathrm{Al}, \mathrm{Fe}$, $\mathrm{Pb}, \mathrm{Cr}, \mathrm{Mn}$, and $\mathrm{U}$, other than increasing significantly after $6 \mathrm{~h}$ for $\mathrm{Pb}$ (Table II). The observed effects of the metals on
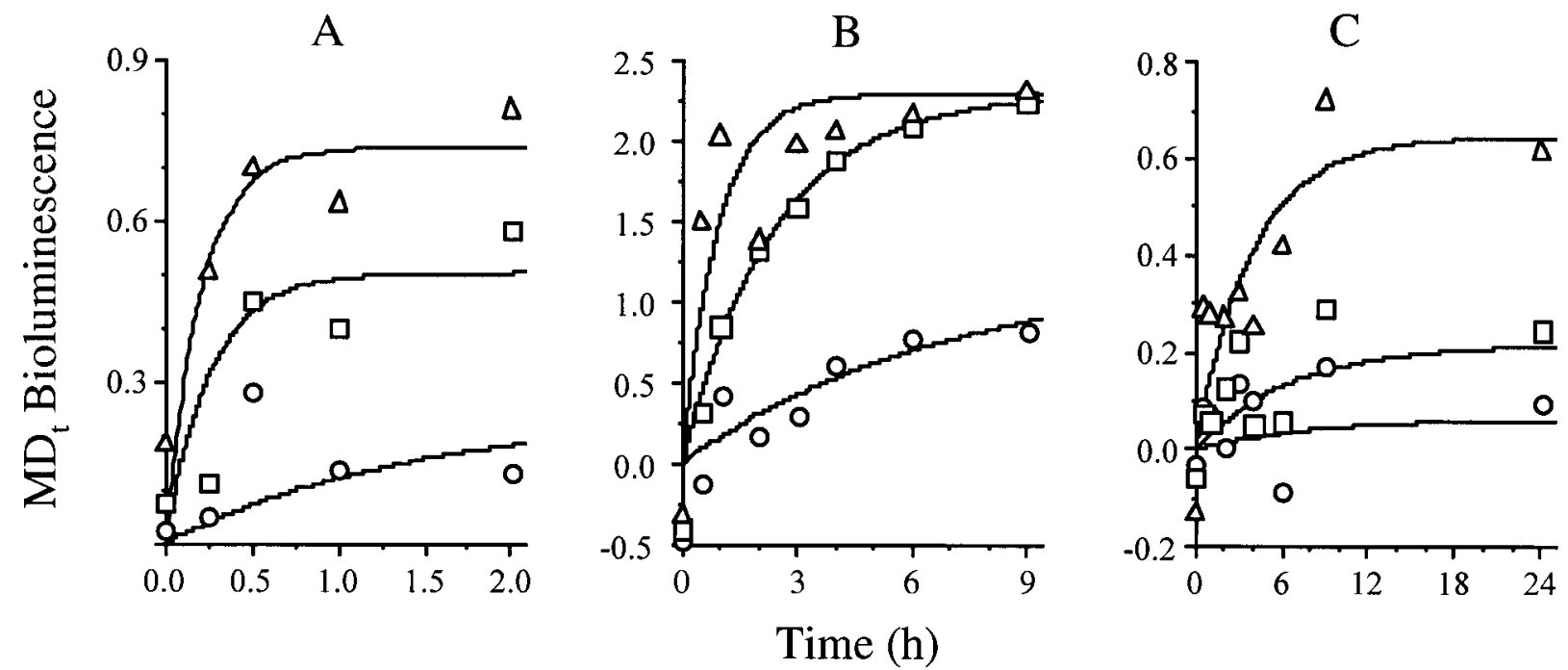

Fig. 2. Exponential models describing values of bioluminescence mean difference from the control $\left(M_{t}\right)$ as a function of time exposure to the three highest total concentrations of $\mathrm{Cd}$ for $(\mathrm{A})$ the Microtox ${ }^{\circledR}$ bioassay, $(\mathrm{B})$ the $P$. phoshoreum bioassay, and (C) the photocyte bioassay (symbols legend: $\triangle, 10^{-3} \mathrm{M} ; \bigcirc, 10^{-4} \mathrm{M} ; \square, 10^{-5} \mathrm{M}$ ). 
the bioluminescence of $P$. phosphoreum were not always related to the effects on bacterial growth. Cell concentration $\mathrm{MD}_{\mathrm{t}}$ decreased significantly for $\mathrm{Ag}, \mathrm{Cd}, \mathrm{Cu}$, and $\mathrm{Hg}$ (Fig. $1)$, with the decrease generally becoming significant after $6 \mathrm{~h}$ of exposure, except for $\mathrm{Ag}(1 \mathrm{~h})$ and $\mathrm{Hg}(3 \mathrm{~h})$, as shown in Table II. There was no significant decrease in the cell concentration $\mathrm{MD}_{t}$ values for $\mathrm{Al}, \mathrm{Cr}, \mathrm{Fe}, \mathrm{Mn}, \mathrm{Pb}, \mathrm{U}$, and $\mathrm{Zn}$, yet, except for $\mathrm{Mn}$ and $\mathrm{Cr}, \mathrm{MD}_{t}$ values were markedly increased on metal exposure; this effect was significant for $\mathrm{Al}$ (negative $\mathrm{MD}_{t}$ values; Table III).

For the photocyte bioassay, bioluminescence $\mathrm{MD}_{t}$ values decreased significantly for $\mathrm{Cd}(2,4,9$, and $24 \mathrm{~h}), \mathrm{Cu}$ (9 and $24 \mathrm{~h})$, and $\mathrm{Hg}$, whereas it was significantly increased for $\mathrm{Cr}$ (6 and 9 h), Mn (0.5-4 h), Pb (0.5 h), and U (4 h), as shown in Table II.

\section{Effect of Concentration}

The effect of total metal concentration on bioluminescence was tested at the longest time exposure for each bioassay ( 2 $\mathrm{h}$ for the Microtox ${ }^{\circledR}$ bioassay, $9 \mathrm{~h}$ for the $P$. phosphoreum bioassay, $24 \mathrm{~h}$ for the photocyte bioassay). For the Microtox ${ }^{\circledR}$ bioassay, typically observed $\mathrm{MD}_{2}$ was significantly decreased at $10^{-3}$ and $10^{-4} \mathrm{M}$ for all metals and at as low as $10^{-5} \mathrm{M}$ for $\mathrm{Ag}, \mathrm{Al}, \mathrm{U}$, and $\mathrm{Zn}$ and $10^{-6} \mathrm{M}$ for $\mathrm{Hg}$ (Table III).

For the $P$. phosphoreum bioassay, the observed bioluminescence $\mathrm{MD}_{9}$ significantly decreased for concentrations $>$ $10^{-6} \mathrm{M}$ for $\mathrm{Ag}$ and $\mathrm{Hg}$, and $>10^{-5} \mathrm{M}$ for $\mathrm{Cd}$ and $\mathrm{Cu}$ (Table III). Similarly, the cell concentration observed $\mathrm{MD}_{9}$ of was significantly decreased for the same metals and concentrations (data not shown). The observed bioluminescence $\mathrm{MD}_{9}$ consistently decreased, although the change was not significant upon exposure to $\mathrm{Cr}$ and $\mathrm{U}$ at concentrations $>10^{-7}$ $\mathrm{M}$, whereas there was no trend in the variation of growth. The observed bioluminescence $\mathrm{MD}_{9}$ significantly increased on exposure to $\mathrm{Al}$ (except $10^{-5} \mathrm{M}$ ), $\mathrm{Pb}, \mathrm{Mn}$ (except $10^{-3}$ $\mathrm{M}$ ), and $\mathrm{Zn}$ (except $10^{-4} \mathrm{M}$ ), as shown in Table III. Similarly, the observed cell concentration $\mathrm{MD}_{9}$ was enhanced for the same metals, expect for Al. The case of Fe exposure was unusual; the observed bioluminescence and cell concentration $\mathrm{MD}_{9}$ values both decreased at concentrations < $10^{-6} \mathrm{M}$ and increased at higher concentrations (Table III).

For the photocyte bioassay, the observed $\mathrm{MD}_{24}$ significantly decreased for $\mathrm{Cd}$ at $10^{-3} \mathrm{M}$, for $\mathrm{Cu}$ at $10^{-3} \mathrm{M}$, and for $\mathrm{Hg}$ at $10^{-6}$ to $10^{-4} \mathrm{M}$. The observed $\mathrm{MD}_{24}$ significantly increased for $\mathrm{Al}$ at $10^{-7} \mathrm{M}$ and for $\mathrm{Mn}$ from $10^{-7}-10^{-4} \mathrm{M}$ (Table III).

The effect of metal exposure over time was modeled for each metal concentration of each bioassay. In general, $\mathrm{MD}_{t}$ values observed at the longest time exposure and $\mathrm{MD}_{\mathrm{eq}}$ values calculated by the model were similar (Table III), indicating that the maximum effects of the metals were reached from the longest time exposure. Exceptions were at lower metal concentrations, meaning that the observed metal effect was not the greatest possible for those concentrations because of the time limit of the bioassay. The kinetic parameter, $k$, increased with metal concentration, suggesting a faster decrease of $\mathrm{MD}_{\text {eq }}$ bioluminescence values for increasing metal concentrations (Table III). For the same metal and metal concentration the kinetics of metal effect were different among bioassays. For $\mathrm{Cd}, \mathrm{Cu}$, and $\mathrm{Hg}$ metals in all three bioassays that had a significant effect on $\mathrm{MD}_{\text {eq }}$ bioluminescence, $k$ was greatest for the Microtox ${ }^{\circledR}$ bioassay and lowest for the photocyte bioassay (Table III).

\section{Metal Speciation}

The highest soluble metal concentration varied among the three media, ranging from $10^{-3} \mathrm{M}$ for the Microtox ${ }^{\circledR}$ bioassay to as low as $10^{-5} \mathrm{M}$ for some metals in the $P$. phosphoreum and photocyte bioassays (Table IV). Ionic strength of the medium varied among the bioassays; it was 0.34 for the Microtox ${ }^{\circledR}$ bioassay, 0.43 for the $P$. phosphoreum bioassay, and 0.61 for the photocyte bioassay. The pH was similar between the Microtox ${ }^{\circledR}$ and photocyte bioassays for a given metal, ranging from 3.5 to 6.4 depending on the element, whereas it was 7.7 for the $P$. phosphoreum bioassay (Table IV). Each bioassay was characterized by the specific chemical speciation of the metal in the corresponding medium; the concentration of free metal ions as well as that of various metal complexes varied depending on the metal, the $\mathrm{pH}$, and the ligands present in the medium (Table IV).

Based on chemical equilibrium computations, metal speciation and corresponding concentrations were similar among the three media for $\mathrm{Ag}, \mathrm{Cd}, \mathrm{Cr}, \mathrm{Hg}, \mathrm{Mn}$, and $\mathrm{Zn}$ (Table IV). Dominant complexes were chlorides occurring in concentrations $\geq$ the free-ion concentration, except for $\mathrm{Cr}$, which formed oxide complexes in concentrations $\leq$ the free-ion concentration.

For $\mathrm{Al}, \mathrm{Cu}$, and $\mathrm{Pb}$, metal speciation and corresponding concentrations were similar between the Microtox ${ }^{\circledR}$ and photocyte bioassays (Table IV). Dominant complexes were hydroxides (Al only), chlorides, and sulfates occurring in concentrations $\leq$ the free ion concentration. According to the thermodynamics calculations, $\mathrm{Al}(\mathrm{OH})_{3}$ was predicted to precipitate, but only in the Microtox ${ }^{\circledR}$ bioassay medium. In the $P$. phosphoreum bioassay medium, Al occurred as a soluble or precipitated hydroxide complex in greater concentrations than as $\mathrm{Al}^{3+}$. Consequently, $\mathrm{Al}^{3+}$ had a lower concentration in this essay than in the other two. The element $\mathrm{Cu}$ formed a soluble hydroxide-citrate or ammonium complex or precipitated as a hydroxide complex in concentrations usually $>$ the free ion form. The $\mathrm{Cu}^{2+}$ concentration in the $P$. phosphoreum bioassay medium was less than that for the other bioassays. The element $\mathrm{Pb}$ occurred in soluble chloride and sulfates complexes or precipitated as carbonate hydroxide in concentrations sim- 
TABLE II. Time course of mean difference from the control $\left(\mathrm{MD}_{\mathbf{t}}\right.$ : mean control value - mean treatment value at time $t$ (exposure) for each metal for the three bioassays

\begin{tabular}{|c|c|c|c|c|c|c|c|c|}
\hline \multirow[b]{2}{*}{ Metal } & \multirow{2}{*}{$\begin{array}{l}\text { Time } \\
\text { (h) }\end{array}$} & \multicolumn{2}{|c|}{ Microtox® } & \multicolumn{3}{|c|}{ P. phosphoreum } & \multicolumn{2}{|c|}{ Photocyte } \\
\hline & & Conc. (M) & $\mathrm{MD}_{t}$ Biolum. & Conc. (M) & $\mathrm{MD}_{t}$ Biolum. & $\mathrm{MD}_{t} \mathrm{OD}$ & Conc. (M) & $\mathrm{MD}_{t}$ Biolum. \\
\hline \multirow[t]{10}{*}{$\mathrm{Ag}$} & 0 & $10^{-3}$ & -0.051 & $10^{-5}$ & 0.056 & 0.043 & $10^{-4}$ & 0.040 \\
\hline & 0.25 & & 0.263 & & NA & NA & & NA \\
\hline & 0.5 & & 0.438 & & 2.165 & 0.075 & & -0.034 \\
\hline & 1 & & 0.616 & & 2.207 & 0.107 & & -0.012 \\
\hline & 2 & & 0.722 & & 2.178 & 0.154 & & -0.003 \\
\hline & 3 & & NA & & 2.140 & 0.221 & & -0.004 \\
\hline & 4 & & NA & & 2.216 & 0.310 & & 0.003 \\
\hline & 6 & & NA & & 2.370 & 0.447 & & 0.047 \\
\hline & 9 & & NA & & 2.579 & 0.642 & & 0.061 \\
\hline & 24 & & NA & & NA & NA & & 0.394 \\
\hline \multirow[t]{10}{*}{ A1 } & 0 & $10^{-3}$ & 0.080 & $10^{-3}$ & 0.041 & 0.044 & $10^{-4}$ & -0.001 \\
\hline & 0.25 & & 0.888 & & NA & NA & & NA \\
\hline & 0.5 & & 1.049 & & 0.362 & -0.081 & & -0.049 \\
\hline & 1 & & 0.992 & & 0.210 & -0.063 & & 0.018 \\
\hline & 2 & & 0.940 & & 0.069 & -0.048 & & 0.026 \\
\hline & 3 & & NA & & -0.081 & -0.016 & & 0.095 \\
\hline & 4 & & NA & & -0.150 & 0.004 & & -0.063 \\
\hline & 6 & & NA & & -0.308 & 0.055 & & -0.103 \\
\hline & 9 & & NA & & -0.468 & 0.086 & & 0.049 \\
\hline & 24 & & NA & & NA & NA & & 0.004 \\
\hline \multirow[t]{10}{*}{$\mathrm{Cd}$} & 0 & $10^{-3}$ & 0.188 & $10^{-3}$ & -0.308 & 0.040 & $10^{-3}$ & -0.128 \\
\hline & 0.25 & & 0.506 & & NA & NA & & NA \\
\hline & 0.5 & & 0.699 & & 1.497 & 0.012 & & 0.294 \\
\hline & 1 & & 0.634 & & 2.033 & 0.045 & & 0.280 \\
\hline & 2 & & 0.811 & & 1.388 & 0.084 & & 0.274 \\
\hline & 3 & & NA & & 1.985 & 0.115 & & 0.325 \\
\hline & 4 & & NA & & 2.065 & 0.168 & & 0.255 \\
\hline & 6 & & NA & & 2.167 & 0.279 & & 0.424 \\
\hline & 9 & & NA & & 2.311 & 0.380 & & 0.723 \\
\hline & 24 & & NA & & NA & NA & & 0.620 \\
\hline \multirow[t]{10}{*}{$\mathrm{Cr}$} & 0 & $10^{-3}$ & 0.142 & $10^{-4}$ & 0.162 & 0.050 & $10^{-3}$ & -0.033 \\
\hline & 0.25 & & 0.283 & & NA & NA & & NA \\
\hline & 0.5 & & 0.422 & & 0.085 & 0.056 & & -0.012 \\
\hline & 1 & & 0.639 & & -0.042 & 0.060 & & -0.099 \\
\hline & 2 & & 0.598 & & 0.132 & 0.034 & & -0.016 \\
\hline & 3 & & NA & & 0.063 & 0.053 & & -0.031 \\
\hline & 4 & & NA & & 0.088 & 0.054 & & 0.061 \\
\hline & 6 & & NA & & 0.113 & 0.097 & & -0.091 \\
\hline & 9 & & NA & & 0.210 & 0.081 & & 0.039 \\
\hline & 24 & & NA & & NA & NA & & -0.015 \\
\hline \multirow[t]{10}{*}{$\mathrm{Cu}$} & 0 & $10^{-3}$ & 0.065 & $10^{-4}$ & -0.175 & -0.027 & $10^{-3}$ & -0.006 \\
\hline & 0.25 & & 0.594 & & NA & NA & & NA \\
\hline & 0.5 & & 0.591 & & 1.850 & 0.033 & & 0.118 \\
\hline & 1 & & 0.544 & & 1.784 & 0.060 & & 0.148 \\
\hline & 2 & & 0.501 & & 1.628 & 0.081 & & 0.124 \\
\hline & 3 & & NA & & 1.669 & 0.146 & & 0.194 \\
\hline & 4 & & NA & & 1.473 & 0.190 & & 0.265 \\
\hline & 6 & & NA & & 1.484 & 0.295 & & 0.471 \\
\hline & 9 & & NA & & 1.087 & 0.430 & & 0.750 \\
\hline & 24 & & NA & & NA & NA & & 1.607 \\
\hline \multirow[t]{5}{*}{$\mathrm{Fe}$} & 0 & $10^{-3}$ & 0.059 & $10^{-4}$ & -0.105 & -0.026 & $10^{-4}$ & -0.029 \\
\hline & 0.25 & & 0.872 & & NA & NA & & NA \\
\hline & 0.5 & & 0.788 & & -0.041 & -0.087 & & 0.016 \\
\hline & 1 & & 0.848 & & -0.098 & -0.081 & & -0.001 \\
\hline & 2 & & 0.787 & & -0.012 & -0.079 & & -0.013 \\
\hline
\end{tabular}


TABLE II. (Continued)

\begin{tabular}{|c|c|c|c|c|c|c|c|c|}
\hline \multirow[b]{2}{*}{ Metal } & \multirow{2}{*}{$\begin{array}{l}\text { Time } \\
\text { (h) }\end{array}$} & \multicolumn{2}{|c|}{ Microtox ${ }^{\circledR}$} & \multicolumn{3}{|c|}{ P. phosphoreum OD } & \multicolumn{2}{|c|}{ Photocyte } \\
\hline & & Conc. (M) & $\mathrm{MD}_{t}$ Biolum. & Conc. (M) & $\mathrm{MD}_{t}$ Biolum. & $\mathrm{MD}_{t} \mathrm{OD}$ & Conc. (M) & $\mathrm{MD}_{t}$ Biolum. \\
\hline & 3 & & NA & & -0.044 & -0.076 & & -0.020 \\
\hline & 4 & & NA & & -0.166 & -0.063 & & 0.014 \\
\hline & 6 & & NA & & -0.156 & -0.059 & & 0.011 \\
\hline & 9 & & NA & & -0.214 & -0.069 & & 0.038 \\
\hline & 24 & & NA & & NA & NA & & 0.037 \\
\hline \multirow[t]{10}{*}{$\mathrm{Hg}$} & 0 & $10^{-3}$ & -0.009 & $10^{-4}$ & 0.003 & -0.079 & $10^{-4}$ & 0.010 \\
\hline & 0.25 & & 0.785 & & NA & NA & & NA \\
\hline & 0.5 & & 0.812 & & 2.071 & -0.008 & & 3.443 \\
\hline & 1 & & 0.903 & & 2.135 & 0.006 & & 3.490 \\
\hline & 2 & & 0.947 & & 2.069 & 0.079 & & 3.476 \\
\hline & 3 & & NA & & 2.051 & 0.157 & & 3.471 \\
\hline & 4 & & NA & & 2.038 & 0.238 & & 3.392 \\
\hline & 6 & & NA & & 1.935 & 0.384 & & 3.405 \\
\hline & 9 & & NA & & 1.619 & 0.545 & & 3.509 \\
\hline & 24 & & NA & & NA & NA & & 3.371 \\
\hline \multirow[t]{10}{*}{$\mathrm{Mn}$} & 0 & $10^{-3}$ & 0.132 & $10^{-3}$ & 0.002 & 0.032 & $10^{-3}$ & -0.049 \\
\hline & 0.25 & & 0.642 & & NA & NA & & NA \\
\hline & 0.5 & & 0.550 & & -0.024 & 0.024 & & -0.057 \\
\hline & 1 & & 0.739 & & -0.032 & 0.018 & & -0.044 \\
\hline & 2 & & 0.683 & & 0.087 & 0.031 & & -0.073 \\
\hline & 3 & & NA & & 0.153 & 0.061 & & -0.050 \\
\hline & 4 & & NA & & 0.221 & 0.110 & & -0.047 \\
\hline & 6 & & NA & & 0.274 & 0.205 & & -0.059 \\
\hline & 9 & & NA & & 0.284 & 0.236 & & -0.065 \\
\hline & 24 & & NA & & NA & NA & & -0.033 \\
\hline \multirow[t]{10}{*}{$\mathrm{Pb}$} & 0 & $10^{-3}$ & -0.104 & $10^{-5}$ & -0.086 & 0.043 & $10^{-5}$ & -0.022 \\
\hline & 0.25 & & 0.936 & & NA & NA & & NA \\
\hline & 0.5 & & 0.878 & & -0.140 & 0.039 & & -0.054 \\
\hline & 1 & & 0.942 & & -0.081 & 0.047 & & -0.028 \\
\hline & 2 & & 0.947 & & -0.103 & 0.023 & & 0.004 \\
\hline & 3 & & NA & & -0.124 & 0.028 & & -0.033 \\
\hline & 4 & & NA & & -0.228 & 0.013 & & -0.034 \\
\hline & 6 & & NA & & -0.407 & -0.010 & & -0.035 \\
\hline & 9 & & NA & & -0.707 & -0.054 & & 0.060 \\
\hline & 24 & & NA & & NA & NA & & -0.008 \\
\hline \multirow[t]{10}{*}{$\mathrm{U}$} & 0 & $10^{-3}$ & -0.037 & $10^{-4}$ & -0.043 & -0.059 & $10^{-4}$ & -0.012 \\
\hline & 0.25 & & 0.922 & & NA & NA & & NA \\
\hline & 0.5 & & 0.847 & & 0.033 & -0.114 & & -0.029 \\
\hline & 1 & & 0.906 & & 0.055 & -0.103 & & -0.025 \\
\hline & 2 & & 0.856 & & 0.115 & -0.113 & & 0.000 \\
\hline & 3 & & NA & & 0.140 & -0.098 & & -0.031 \\
\hline & 4 & & NA & & 0.116 & -0.065 & & -0.031 \\
\hline & 6 & & NA & & 0.014 & 0.010 & & 0.037 \\
\hline & 9 & & NA & & 0.221 & 0.100 & & -0.016 \\
\hline & 24 & & NA & & & NA & & -0.024 \\
\hline \multirow[t]{10}{*}{$\mathrm{Zn}$} & 0 & $10^{-3}$ & 0.056 & $10^{-4}$ & 0.041 & -0.079 & $10^{-4}$ & 0.022 \\
\hline & 0.25 & & 0.638 & & NA & NA & & NA \\
\hline & 0.5 & & 0.602 & & 0.586 & -0.093 & & -0.017 \\
\hline & 1 & & 0.648 & & 0.648 & -0.082 & & -0.017 \\
\hline & 2 & & 0.573 & & 0.563 & -0.050 & & 0.006 \\
\hline & 3 & & NA & & 0.563 & -0.007 & & 0.001 \\
\hline & 4 & & NA & & 0.584 & 0.027 & & 0.022 \\
\hline & 6 & & NA & & 0.725 & 0.101 & & 0.046 \\
\hline & 9 & & NA & & 0.725 & 0.226 & & 0.021 \\
\hline & 24 & & NA & & NA & NA & & 0.045 \\
\hline
\end{tabular}

Only highest metal total concentration is shown. Mean difference values in bold (positive $\left.\mathrm{MD}_{t}\right)$ and bold italics (negative $\left.\mathrm{MD}_{t}\right)$ are significant $(P \leq$ $0.05)$. NA: not analyzed. 
TABLE III. Mean difference of bioluminescence for the control (MD: mean control value-mean treatment value) observed at longest time exposure, and parameters $\left(\mathrm{MD}_{\mathrm{eq}}, \mathrm{k}\right.$, and $\left.R^{2}\right)$ of the exponential model describing change in the mean difference between the control and the treatment

\begin{tabular}{|c|c|c|c|c|c|c|c|c|c|c|c|c|c|}
\hline \multirow[b]{2}{*}{ Metal } & \multirow[b]{2}{*}{$\begin{array}{l}{[\text { Metal }]_{\text {Tot }}} \\
\text { (M) }\end{array}$} & \multicolumn{4}{|c|}{ Microtox ${ }^{\circledR}$} & \multicolumn{4}{|c|}{ P. phosphoreum } & \multicolumn{4}{|c|}{ Photocyte } \\
\hline & & $\begin{array}{c}\text { Observed } \\
\mathrm{MD}_{2}\end{array}$ & $\begin{array}{l}\text { Model } \\
\text { MD }_{\text {eq }}\end{array}$ & $\mathrm{k}$ & $R^{2}$ & $\begin{array}{c}\text { Observed } \\
\mathrm{MD}_{9}\end{array}$ & $\begin{array}{l}\text { Model } \\
\text { MD }_{\text {eq }}\end{array}$ & $\mathrm{k}$ & $R^{2}$ & $\begin{array}{c}\text { Observed } \\
\mathrm{MD}_{24}\end{array}$ & $\begin{array}{l}\text { Model } \\
\text { MD }_{\text {eq }}\end{array}$ & $\mathrm{k}$ & $R^{2}$ \\
\hline $\mathrm{Ag}$ & $\begin{array}{l}10^{-8} \\
10^{-7} \\
10^{-6} \\
10^{-5} \\
10^{-4} \\
10^{-3}\end{array}$ & $\begin{array}{l}0.001 \\
0.038 \\
0.031 \\
\mathbf{0 . 5 8 3} \\
0.558 \\
\mathbf{0 . 7 2 2}\end{array}$ & $\begin{array}{r}-0.06 \\
0.04 \\
0.04 \\
0.67 \\
0.56 \\
0.74\end{array}$ & $\begin{array}{l}1.50 \\
1.72 \\
0.75 \\
0.89 \\
2.84 \\
1.77\end{array}$ & $\begin{array}{l}0.41 \\
0.60 \\
0.72 \\
0.95 \\
0.99 \\
1.00\end{array}$ & $\begin{array}{l}0.945 \\
0.700 \\
\mathbf{1 . 8 3 3} \\
\mathbf{2 . 5 7 9} \\
\text { NA } \\
\text { NA }\end{array}$ & $\begin{array}{l}1.30 \\
1.20 \\
1.85 \\
2.27 \\
\text { NA } \\
\text { NA }\end{array}$ & $\begin{array}{l}0.10 \\
0.07 \\
0.48 \\
3.46 \\
\text { NA } \\
\text { NA }\end{array}$ & $\begin{array}{l}0.83 \\
0.51 \\
0.99 \\
0.95 \\
\text { NA } \\
\text { NA }\end{array}$ & $\begin{array}{c}-0.047 \\
-0.032 \\
-0.019 \\
-0.006 \\
0.394 \\
\text { NA }\end{array}$ & $\begin{array}{r}-0.07 \\
-0.03 \\
-0.03 \\
-0.02 \\
0.25 \\
\text { NA }\end{array}$ & $\begin{array}{l}0.02 \\
0.10 \\
0.10 \\
0.20 \\
0.07 \\
\text { NA }\end{array}$ & $\begin{array}{r}0.70 \\
0.02 \\
0.02 \\
0.04 \\
0.77 \\
\text { NA }\end{array}$ \\
\hline $\mathrm{Al}$ & $\begin{array}{l}10^{-8} \\
10^{-7} \\
10^{-6} \\
10^{-5} \\
10^{-4} \\
10^{-3}\end{array}$ & $\begin{array}{l}0.133 \\
0.120 \\
\mathbf{0 . 1 8 6} \\
\mathbf{0 . 4 2 3} \\
\mathbf{0 . 7 5 3} \\
\mathbf{0 . 9 4 0}\end{array}$ & $\begin{array}{l}0.18 \\
0.18 \\
0.20 \\
0.39 \\
0.74 \\
0.99\end{array}$ & $\begin{array}{l}0.90 \\
2.00 \\
1.80 \\
5.17 \\
3.57 \\
9.49\end{array}$ & $\begin{array}{l}0.02 \\
0.02 \\
0.12 \\
0.74 \\
0.92 \\
0.99\end{array}$ & $\begin{array}{r}0.030 \\
-0.034 \\
-0.158 \\
0.023 \\
-0.127 \\
-0.468\end{array}$ & $\begin{array}{r}0.08 \\
0.07 \\
0.05 \\
0.15 \\
0.15 \\
-0.44\end{array}$ & $\begin{array}{l}0.15 \\
0.40 \\
0.30 \\
0.30 \\
0.10 \\
0.11\end{array}$ & $\begin{array}{l}0.07 \\
0.28 \\
0.18 \\
0.14 \\
0.69 \\
0.77\end{array}$ & $\begin{array}{r}0.001 \\
-\boldsymbol{0 . 0 5 1} \\
-0.022 \\
0.065 \\
0.004 \\
\text { NA }\end{array}$ & $\begin{array}{c}0.01 \\
-0.07 \\
0.002 \\
0.06 \\
0.01 \\
\text { NA }\end{array}$ & $\begin{array}{l}0.10 \\
0.09 \\
0.04 \\
0.08 \\
0.09 \\
\text { NA }\end{array}$ & $\begin{array}{l}0.002 \\
0.27 \\
0.01 \\
0.08 \\
0.002 \\
\text { NA }\end{array}$ \\
\hline $\mathrm{Cd}$ & $\begin{array}{l}10^{-8} \\
10^{-7} \\
10^{-6} \\
10^{-5} \\
10^{-4} \\
10^{-3}\end{array}$ & $\begin{array}{l}0.192 \\
0.055 \\
0.047 \\
0.131 \\
\mathbf{0 . 5 8 3} \\
\mathbf{0 . 8 1 1}\end{array}$ & $\begin{array}{l}0.22 \\
0.15 \\
0.18 \\
0.20 \\
0.58 \\
0.74\end{array}$ & $\begin{array}{l}0.70 \\
0.90 \\
0.80 \\
0.90 \\
1.66 \\
4.83\end{array}$ & $\begin{array}{l}0.42 \\
0.01 \\
0.08 \\
0.13 \\
0.84 \\
0.89\end{array}$ & $\begin{array}{l}0.172 \\
0.305 \\
0.414 \\
\mathbf{0 . 8 2 5} \\
\mathbf{2 . 2 4 5} \\
\mathbf{2 . 3 1 1}\end{array}$ & $\begin{array}{r}-0.05 \\
0.37 \\
0.42 \\
1.20 \\
2.29 \\
2.29\end{array}$ & $\begin{array}{l}0.16 \\
0.22 \\
0.30 \\
0.14 \\
0.41 \\
1.07\end{array}$ & $\begin{array}{l}0.35 \\
0.74 \\
0.84 \\
0.78 \\
0.98 \\
0.79\end{array}$ & $\begin{array}{l}0.162 \\
0.043 \\
0.094 \\
0.094 \\
0.244 \\
\mathbf{0 . 6 2 0}\end{array}$ & $\begin{array}{l}0.21 \\
0.16 \\
0.10 \\
0.12 \\
0.25 \\
0.64\end{array}$ & $\begin{array}{l}0.07 \\
0.04 \\
0.09 \\
0.15 \\
0.22 \\
0.25\end{array}$ & $\begin{array}{l}0.25 \\
0.09 \\
0.49 \\
0.07 \\
0.52 \\
0.72\end{array}$ \\
\hline $\mathrm{Cr}$ & $\begin{array}{l}10^{-8} \\
10^{-7} \\
10^{-6} \\
10^{-5} \\
10^{-4} \\
10^{-3}\end{array}$ & $\begin{array}{l}0.127 \\
0.119 \\
0.278 \\
0.230 \\
\mathbf{0 . 4 1 7} \\
\mathbf{0 . 5 9 8}\end{array}$ & $\begin{array}{l}0.18 \\
0.12 \\
0.30 \\
0.23 \\
0.43 \\
0.64\end{array}$ & $\begin{array}{r}0.90 \\
4.56 \\
10.00 \\
13.68 \\
1.49 \\
2.43\end{array}$ & $\begin{array}{l}0.05 \\
0.93 \\
0.92 \\
0.48 \\
0.91 \\
0.92\end{array}$ & $\begin{array}{c}-0.082 \\
0.253 \\
0.310 \\
0.280 \\
0.210 \\
\text { NA }\end{array}$ & $\begin{array}{r}-0.17 \\
0.17 \\
0.13 \\
-0.01 \\
0.18 \\
\text { NA }\end{array}$ & $\begin{array}{l}0.67 \\
0.40 \\
0.40 \\
0.04 \\
0.40 \\
\text { NA }\end{array}$ & $\begin{array}{l}0.08 \\
0.74 \\
0.56 \\
0.31 \\
0.06 \\
\text { NA }\end{array}$ & $\begin{array}{r}-0.042 \\
-0.017 \\
0.009 \\
-0.065 \\
-0.037 \\
-0.015\end{array}$ & $\begin{array}{r}-0.05 \\
-0.03 \\
-0.03 \\
-0.04 \\
-0.01 \\
0.01\end{array}$ & $\begin{array}{l}0.40 \\
0.40 \\
0.40 \\
0.40 \\
0.40 \\
0.42\end{array}$ & $\begin{array}{l}0.001 \\
0.01 \\
0.04 \\
0.01 \\
0.13 \\
0.06\end{array}$ \\
\hline $\mathrm{Cu}$ & $\begin{array}{l}10^{-8} \\
10^{-7} \\
10^{-6} \\
10^{-5} \\
10^{-4} \\
10^{-3}\end{array}$ & $\begin{array}{l}0.020 \\
0.133 \\
0.175 \\
0.333 \\
\mathbf{0 . 4 7 7} \\
\mathbf{0 . 5 0 1}\end{array}$ & $\begin{array}{r}-0.01 \\
0.18 \\
0.25 \\
0.30 \\
0.51 \\
0.54\end{array}$ & $\begin{array}{r}0.40 \\
0.90 \\
0.80 \\
4.63 \\
23.45 \\
20.31\end{array}$ & $\begin{array}{l}0.64 \\
0.67 \\
0.64 \\
0.86 \\
0.95 \\
0.95\end{array}$ & $\begin{array}{r}-0.414 \\
0.010 \\
-0.106 \\
\mathbf{1 . 1 0 6} \\
\mathbf{1 . 0 8 7} \\
\text { NA }\end{array}$ & $\begin{array}{c}-0.31 \\
-0.05 \\
-0.29 \\
1.42 \\
1.50 \\
\text { NA }\end{array}$ & $\begin{array}{r}0.89 \\
0.40 \\
0.63 \\
1.21 \\
13.72 \\
\text { NA }\end{array}$ & $\begin{array}{l}0.01 \\
0.21 \\
0.15 \\
0.91 \\
0.87 \\
\text { NA }\end{array}$ & $\begin{array}{r}-0.069 \\
1.347 \\
-0.016 \\
0.021 \\
0.186 \\
\mathbf{1 . 6 0 7}\end{array}$ & $\begin{array}{r}0.01 \\
0.17 \\
-0.01 \\
0.05 \\
0.18 \\
2.95\end{array}$ & $\begin{array}{l}0.04 \\
0.31 \\
0.34 \\
0.40 \\
0.13 \\
0.03\end{array}$ & $\begin{array}{l}0.12 \\
0.25 \\
0.07 \\
0.49 \\
0.73 \\
0.99\end{array}$ \\
\hline $\mathrm{Fe}$ & $\begin{array}{l}10^{-8} \\
10^{-7} \\
10^{-6} \\
10^{-5} \\
10^{-4} \\
10^{-3}\end{array}$ & $\begin{array}{r}0.114 \\
-0.052 \\
0.037 \\
0.022 \\
\mathbf{0 . 8 2 4} \\
\mathbf{0 . 7 8 7}\end{array}$ & $\begin{array}{r}0.18 \\
-0.10 \\
0.02 \\
0.05 \\
0.76 \\
0.80\end{array}$ & $\begin{array}{r}1.50 \\
0.80 \\
0.40 \\
4.00 \\
11.48 \\
17.77\end{array}$ & $\begin{array}{l}0.00 \\
0.03 \\
0.62 \\
0.41 \\
0.98 \\
0.98\end{array}$ & $\begin{array}{r}0.374 \\
\mathbf{0 . 4 0 3} \\
0.290 \\
-0.082 \\
-0.214 \\
\text { NA }\end{array}$ & $\begin{array}{c}0.36 \\
0.32 \\
0.10 \\
-0.05 \\
-0.18 \\
\text { NA }\end{array}$ & $\begin{array}{l}1.06 \\
0.23 \\
0.27 \\
0.40 \\
0.40 \\
\text { NA }\end{array}$ & $\begin{array}{l}0.84 \\
0.93 \\
0.66 \\
0.42 \\
0.30 \\
\text { NA }\end{array}$ & $\begin{array}{r}0.011 \\
-0.013 \\
0.002 \\
-0.003 \\
0.037 \\
\text { NA }\end{array}$ & $\begin{array}{r}-0.01 \\
-0.01 \\
-0.01 \\
0.02 \\
0.04 \\
\text { NA }\end{array}$ & $\begin{array}{l}0.40 \\
0.40 \\
0.40 \\
0.25 \\
0.15 \\
\text { NA }\end{array}$ & $\begin{array}{l}0.005 \\
0.42 \\
0.14 \\
0.21 \\
0.47 \\
\text { NA }\end{array}$ \\
\hline $\mathrm{Hg}$ & $\begin{array}{l}10^{-8} \\
10^{-7} \\
10^{-6} \\
10^{-5} \\
10^{-4} \\
10^{-3}\end{array}$ & $\begin{array}{l}0.012 \\
0.041 \\
\mathbf{0 . 9 7 7} \\
\mathbf{0 . 9 8 9} \\
\mathbf{0 . 9 4 2} \\
\mathbf{0 . 9 4 7}\end{array}$ & $\begin{array}{r}-0.10 \\
-0.02 \\
0.93 \\
0.93 \\
0.88 \\
0.90\end{array}$ & $\begin{array}{r}0.90 \\
0.70 \\
9.97 \\
15.33 \\
12.05 \\
6.28\end{array}$ & $\begin{array}{l}0.24 \\
0.43 \\
0.98 \\
0.98 \\
0.97 \\
0.99\end{array}$ & $\begin{array}{r}-0.115 \\
-0.362 \\
\mathbf{1 . 3 5 9} \\
\mathbf{1 . 6 1 9} \\
\mathbf{1 . 6 1 9} \\
\text { NA }\end{array}$ & $\begin{array}{c}-0.05 \\
-0.40 \\
1.76 \\
1.97 \\
1.97 \\
\text { NA }\end{array}$ & $\begin{array}{l}0.01 \\
0.08 \\
6.76 \\
9.56 \\
9.56 \\
\text { NA }\end{array}$ & $\begin{array}{l}0.14 \\
0.23 \\
0.94 \\
0.95 \\
0.95 \\
\text { NA }\end{array}$ & $\begin{array}{r}-0.083 \\
-0.001 \\
\mathbf{1 . 6 1 5} \\
\mathbf{3 . 3 5 7} \\
\mathbf{3 . 3 7 1} \\
\text { NA }\end{array}$ & $\begin{array}{r}0.01 \\
-0.01 \\
3.29 \\
3.28 \\
3.44 \\
\text { NA }\end{array}$ & $\begin{array}{l}0.10 \\
0.04 \\
0.02 \\
0.53 \\
5.98 \\
\text { NA }\end{array}$ & $\begin{array}{r}0.01 \\
0.05 \\
0.99 \\
0.96 \\
1.00 \\
\text { NA }\end{array}$ \\
\hline Mn & $\begin{array}{l}10^{-8} \\
10^{-7} \\
10^{-6} \\
10^{-5} \\
10^{-4} \\
10^{-3}\end{array}$ & $\begin{array}{l}0.022 \\
0.062 \\
0.179 \\
0.155 \\
\mathbf{0 . 5 4 7} \\
\mathbf{0 . 6 8 3}\end{array}$ & $\begin{array}{r}-0.02 \\
0.07 \\
0.17 \\
0.10 \\
0.57 \\
0.67\end{array}$ & $\begin{array}{l}0.80 \\
0.70 \\
4.21 \\
1.00 \\
1.77 \\
9.76\end{array}$ & $\begin{array}{l}0.69 \\
0.43 \\
0.95 \\
0.88 \\
0.98 \\
0.91\end{array}$ & $\begin{array}{r}-0.368 \\
-0.042 \\
-0.411 \\
-0.092 \\
-0.546 \\
0.284\end{array}$ & $\begin{array}{r}-0.38 \\
-0.10 \\
-0.49 \\
-0.13 \\
-0.50 \\
0.30\end{array}$ & $\begin{array}{l}0.33 \\
0.40 \\
0.11 \\
0.62 \\
0.40 \\
0.30\end{array}$ & $\begin{array}{l}0.80 \\
0.51 \\
0.85 \\
0.62 \\
0.81 \\
0.88\end{array}$ & $\begin{array}{r}0.017 \\
-0.076 \\
-0.068 \\
-0.077 \\
-0.070 \\
-0.033\end{array}$ & $\begin{array}{l}-0.02 \\
-0.05 \\
-0.06 \\
-0.06 \\
-0.06 \\
-0.05\end{array}$ & $\begin{array}{l}0.10 \\
0.06 \\
0.06 \\
0.07 \\
0.07 \\
0.08\end{array}$ & $\begin{array}{l}0.09 \\
0.01 \\
0.01 \\
0.03 \\
0.02 \\
0.01\end{array}$ \\
\hline $\mathrm{Pb}$ & $\begin{array}{l}10^{-8} \\
10^{-7} \\
10^{-6} \\
10^{-5} \\
10^{-4} \\
10^{-3}\end{array}$ & $\begin{array}{r}-0.052 \\
-0.091 \\
0.156 \\
0.477 \\
\mathbf{0 . 8 6 6} \\
\mathbf{0 . 9 4 7}\end{array}$ & $\begin{array}{r}-0.10 \\
-0.10 \\
0.20 \\
0.54 \\
0.86 \\
0.92\end{array}$ & $\begin{array}{r}1.00 \\
1.00 \\
9.72 \\
3.61 \\
8.32 \\
12.68\end{array}$ & $\begin{array}{l}0.06 \\
0.09 \\
0.92 \\
0.94 \\
1.00 \\
0.99\end{array}$ & $\begin{array}{c}-0.380 \\
-0.507 \\
-0.568 \\
-0.707 \\
\text { NA } \\
\text { NA }\end{array}$ & $\begin{array}{c}-0.19 \\
-0.37 \\
-0.44 \\
-0.56 \\
\text { NA } \\
\text { NA }\end{array}$ & $\begin{array}{l}0.28 \\
0.11 \\
0.19 \\
0.23 \\
\text { NA } \\
\text { NA }\end{array}$ & $\begin{array}{l}0.66 \\
0.74 \\
0.70 \\
0.68 \\
\text { NA } \\
\text { NA }\end{array}$ & $\begin{array}{c}-0.030 \\
-0.043 \\
-0.032 \\
-0.008 \\
\text { NA } \\
\text { NA }\end{array}$ & $\begin{array}{l}-0.04 \\
-0.03 \\
-0.04 \\
-0.001 \\
\text { NA } \\
\text { NA }\end{array}$ & $\begin{array}{l}0.10 \\
0.21 \\
0.08 \\
0.05 \\
\text { NA } \\
\text { NA }\end{array}$ & $\begin{array}{r}0.03 \\
0.03 \\
0.00 \\
0.13 \\
\text { NA } \\
\text { NA }\end{array}$ \\
\hline $\mathrm{U}$ & $\begin{array}{l}10^{-8} \\
10^{-7} \\
10^{-6} \\
10^{-5} \\
10^{-4} \\
10^{-3}\end{array}$ & $\begin{array}{r}0.034 \\
-0.033 \\
0.106 \\
\mathbf{0 . 8 6 2} \\
\mathbf{0 . 8 8 3} \\
\mathbf{0 . 8 5 6}\end{array}$ & $\begin{array}{r}-0.05 \\
-0.08 \\
0.12 \\
0.90 \\
0.88 \\
0.87\end{array}$ & $\begin{array}{r}4.00 \\
3.00 \\
3.20 \\
3.84 \\
5.36 \\
15.59\end{array}$ & $\begin{array}{l}0.20 \\
0.02 \\
0.94 \\
0.99 \\
0.99 \\
0.99\end{array}$ & $\begin{array}{r}-0.025 \\
0.124 \\
\mathbf{0 . 4 7 9} \\
-0.015 \\
0.221 \\
\text { NA }\end{array}$ & $\begin{array}{l}0.05 \\
0.18 \\
0.29 \\
0.03 \\
0.14 \\
\text { NA }\end{array}$ & $\begin{array}{l}0.60 \\
0.37 \\
0.16 \\
0.60 \\
0.49 \\
\text { NA }\end{array}$ & $\begin{array}{l}0.03 \\
0.64 \\
0.70 \\
0.03 \\
0.50 \\
\text { NA }\end{array}$ & $\begin{array}{r}0.015 \\
-0.021 \\
-0.018 \\
0.027 \\
-0.024 \\
\text { NA }\end{array}$ & $\begin{array}{r}0.01 \\
-0.02 \\
-0.02 \\
0.02 \\
-0.02 \\
\text { NA }\end{array}$ & $\begin{array}{l}0.08 \\
0.08 \\
0.08 \\
0.10 \\
0.14 \\
\text { NA }\end{array}$ & $\begin{array}{l}0.23 \\
0.002 \\
0.002 \\
0.34 \\
0.02 \\
\text { NA }\end{array}$ \\
\hline $\mathrm{Zn}$ & $\begin{array}{l}10^{-8} \\
10^{-7} \\
10^{-6} \\
10^{-5} \\
10^{-4} \\
10^{-3}\end{array}$ & $\begin{array}{l}0.030 \\
0.152 \\
0.228 \\
\mathbf{0 . 3 9 9} \\
\mathbf{0 . 4 6 6} \\
\mathbf{0 . 5 7 3}\end{array}$ & $\begin{array}{l}0.03 \\
0.14 \\
0.23 \\
0.40 \\
0.55 \\
0.60\end{array}$ & $\begin{array}{r}2.28 \\
2.64 \\
3.68 \\
1.99 \\
4.94 \\
15.85\end{array}$ & $\begin{array}{l}0.68 \\
0.90 \\
0.86 \\
0.98 \\
0.93 \\
0.97\end{array}$ & $\begin{array}{c}-0.587 \\
-0.959 \\
-\mathbf{0 . 9 4 4} \\
-0.676 \\
0.725 \\
\text { NA }\end{array}$ & $\begin{array}{c}-0.30 \\
-0.49 \\
-0.59 \\
-0.52 \\
0.63 \\
\text { NA }\end{array}$ & $\begin{array}{l}0.34 \\
0.38 \\
0.16 \\
0.16 \\
3.64 \\
\text { NA }\end{array}$ & $\begin{array}{l}0.66 \\
0.59 \\
0.66 \\
0.66 \\
0.44 \\
\text { NA }\end{array}$ & $\begin{array}{c}-0.051 \\
-0.033 \\
-0.041 \\
0.001 \\
0.045 \\
\text { NA }\end{array}$ & $\begin{array}{l}-0.05 \\
-0.03 \\
-0.03 \\
0.002 \\
0.05 \\
\text { NA }\end{array}$ & $\begin{array}{l}0.10 \\
0.13 \\
0.20 \\
0.20 \\
0.10 \\
\text { NA }\end{array}$ & $\begin{array}{l}0.28 \\
0.09 \\
0.23 \\
0.001 \\
0.51 \\
\text { NA }\end{array}$ \\
\hline
\end{tabular}

See Methods section for model description. Mean difference values in bold (positive MD) and bold italics (negative MD) are significant $(P \leq 0.05)$. NA: not analyzed. 
TABLE IV. Concentrations of free metal ions and dominant forms of metal complexes for each element assessed with the three bioassays, and $\mathrm{pH}$ of each medium after addition of metal salt, as calculated by the HYDRAQL program

\begin{tabular}{|c|c|c|c|c|c|c|c|c|c|c|}
\hline \multirow[b]{2}{*}{ Metal salt } & \multirow{2}{*}{$\begin{array}{l}{[\text { Metal }]_{\text {Tot }}} \\
(\mathrm{M})\end{array}$} & \multicolumn{3}{|c|}{ Microtox® } & \multicolumn{3}{|c|}{ P. phosphoreum } & \multicolumn{3}{|c|}{ Photocyte } \\
\hline & & $\mathrm{pH}$ & Chemical form & Conc. (M) & $\mathrm{pH}$ & Chemical form & Conc. (M) & $\mathrm{pH}$ & Chemical form & Conc. (M) \\
\hline \multirow[t]{4}{*}{$\mathrm{AgNO}_{3}(\mathrm{Ag})$} & $10^{-5}$ & 5.5 & $\mathrm{Ag}^{+}$ & $5.8 \times 10^{-11}$ & 7.7 & $\mathrm{Ag}^{+}$ & $7.4 \times 10^{-11}$ & 5.5 & $\mathrm{Ag}^{+}$ & $2.2 \times 10^{-11}$ \\
\hline & & & $\mathrm{AgCl}_{3}^{2-}$ & $5.8 \times 10^{-6}$ & & $\mathrm{AgCl}_{3}^{2-}$ & $6.0 \times 10^{-6}$ & & $\mathrm{AgCl}_{3}^{2-}$ & $6.7 \times 10^{-6}$ \\
\hline & & & $\mathrm{AgCl}_{4}^{3-}$ & $3.5 \times 10^{-6}$ & & $\mathrm{AgCl}_{4}^{3-}$ & $3.3 \times 10^{-6}$ & & $\mathrm{AgCl}_{4}^{3-}$ & $3.0 \times 10^{-6}$ \\
\hline & & & $\mathrm{AgCl}_{2}^{-}$ & $6.5 \times 10^{-7}$ & & $\mathrm{AgCl}_{2}^{-}$ & $7.1 \times 10^{-7}$ & & $\mathrm{AgCl}_{2}^{-}$ & $2.6 \times 10^{-7}$ \\
\hline \multirow[t]{5}{*}{$\mathrm{Al}_{2}\left(\mathrm{SO}_{4}\right)_{3}(\mathrm{Al})$} & $10^{-4}$ & 4.4 & $\mathrm{Al}^{3+}$ & $1.7 \times 10^{-4}$ & 7.7 & $\mathrm{Al}^{3+}$ & $1.4 \times 10^{-14}$ & 4.8 & $\mathrm{Al}^{3+}$ & $1.3 \times 10^{-4}$ \\
\hline & & & $\mathrm{Al}(\mathrm{OH})^{2+}$ & $1.2 \times 10^{-5}$ & & $\mathrm{Al}(\mathrm{OH})_{4}^{-}$ & $6.6 \times 10^{-7}$ & & $\mathrm{Al}\left(\mathrm{SO}_{4}\right)^{+}$ & $6.2 \times 10^{-5}$ \\
\hline & & & $\mathrm{Al}(\mathrm{OH})_{2}^{+}$ & $6.9 \times 10^{-6}$ & & $\mathrm{Al}(\mathrm{OH})_{3}^{0}$ & $3.2 \times 10^{-7}$ & & $\left.\mathrm{Al}(\mathrm{OH})_{2}^{+}\right)$ & $6.0 \times 10^{-6}$ \\
\hline & & & $\mathrm{Al}\left(\mathrm{SO}_{4}\right)^{+}$ & $4.4 \times 10^{-6}$ & & $\mathrm{Al}(\mathrm{OH})_{3}(\mathrm{~s})$ & $2.0 \times 10^{-4}$ & & $\mathrm{Al}(\mathrm{OH})^{2+}$ & $2.8 \times 10^{-6}$ \\
\hline & & & $\mathrm{Al}(\mathrm{OH})_{3} \quad(\mathrm{~s})$ & $5.5 \times 10^{-6}$ & & & & & & \\
\hline \multirow[t]{5}{*}{$\mathrm{CdCl}_{2}(\mathrm{Cd})$} & $10^{-3}$ & 5.5 & $\mathrm{Cd}^{2+}$ & $5.2 \times 10^{-5}$ & 7.7 & $\mathrm{Cd}^{2+}$ & $5.7 \times 10^{-5}$ & 5.5 & $\mathrm{Cd}^{2+}$ & $2.4 \times 10^{-5}$ \\
\hline & & & $\mathrm{CdCl}^{+}$ & $4.9 \times 10^{-4}$ & & $\mathrm{CdCl}^{+}$ & $4.9 \times 10^{-4}$ & & $\mathrm{CdCl}^{+}$ & $5.2 \times 10^{-4}$ \\
\hline & & & $\mathrm{CdCl}_{2}$ & $3.8 \times 10^{-4}$ & & $\mathrm{CdCl}_{2}$ & $3.5 \times 10^{-4}$ & & $\mathrm{CdCl}_{2}$ & $3.7 \times 10^{-4}$ \\
\hline & & & $\mathrm{CdCl}_{3}^{-}$ & $8.1 \times 10^{-5}$ & & $\mathrm{CdCl}_{3}^{-}$ & $7.1 \times 10^{-5}$ & & $\mathrm{CdCl}_{3}^{-}$ & $8.0 \times 10^{-5}$ \\
\hline & & & & & & $\mathrm{CdSO}_{4}$ & $2.4 \times 10^{-5}$ & & $\mathrm{CdSO}_{4}$ & $1.5 \times 10^{-6}$ \\
\hline \multirow[t]{4}{*}{$\mathrm{Na}_{2} \mathrm{CrO}_{4}(\mathrm{Cr})$} & $10^{-4}$ & 6.4 & $\mathrm{CrO}_{4}^{2-}$ & $5.3 \times 10^{-5}$ & 7.7 & $\mathrm{CrO}_{4}^{2-}$ & $7.6 \times 10^{-5}$ & 6.2 & $\mathrm{CrO}_{4}^{2-}$ & $7.6 \times 10^{-5}$ \\
\hline & & & $\mathrm{NaCrO}_{4}^{-}$ & $2.6 \times 10^{-5}$ & & $\mathrm{KCrO}_{4}^{-}$ & $2.2 \times 10^{-5}$ & & $\mathrm{HCrO}_{4}^{-}$ & $1.3 \times 10^{-5}$ \\
\hline & & & $\mathrm{HCrO}_{4}^{-}$ & $2.1 \times 10^{-5}$ & & $\mathrm{HCrO}_{4}^{-}$ & $1.3 \times 10^{-6}$ & & $\mathrm{NaCrO}_{4}^{-}$ & $1.1 \times 10^{-5}$ \\
\hline & & & & & & $\mathrm{NaCrO}_{4}^{-}$ & $3.2 \times 10^{-7}$ & & $\mathrm{KCrO}_{4}^{-}$ & $1.4 \times 10^{-7}$ \\
\hline \multirow[t]{4}{*}{$\mathrm{CuCl}_{2}(\mathrm{Cu})$} & $10^{-4}$ & 5.5 & $\mathrm{Cu}^{2+}$ & $7.4 \times 10^{-5}$ & 7.7 & $\mathrm{Cu}^{2+}$ & $2.7 \times 10^{-8}$ & 5.5 & $\mathrm{Cu}^{2+}$ & $7.4 \times 10^{-5}$ \\
\hline & & & $\mathrm{CuCl}^{+}$ & $2.3 \times 10^{-5}$ & & $\mathrm{Cu}_{2}(\mathrm{OH})_{2} \mathrm{Citr}_{2}$ & $3.8 \times 10^{-7}$ & & $\mathrm{CuCl}^{+}$ & $2.1 \times 10^{-5}$ \\
\hline & & & $\mathrm{CuCl}_{2}$ & $3.3 \times 10^{-6}$ & & $\mathrm{Cu}\left(\mathrm{NH}_{3}\right)_{2}$ & $8.2 \times 10^{-8}$ & & $\mathrm{CuCl}_{2}$ & $2.6 \times 10^{-6}$ \\
\hline & & & & & & $\mathrm{Cu}(\mathrm{OH})_{2}(\mathrm{~s})$ & $9.9 \times 10^{-5}$ & & $\mathrm{CuSO}_{4}$ & $2.4 \times 10^{-6}$ \\
\hline \multirow[t]{3}{*}{$\mathrm{FeCl}_{3}(\mathrm{Fe})$} & $10^{-4}$ & 3.5 & $\mathrm{Fe}^{3+}$ & $3.5 \times 10^{-11}$ & 7.7 & $\mathrm{Fe}^{3+}$ & $8.6 \times 10^{-24}$ & 3.6 & $\mathrm{Fe}^{3+}$ & $9.1 \times 10^{-10 a}$ \\
\hline & & & $\mathrm{Fe}(\mathrm{OH})^{+}$ & $2.2 \times 10^{-10}$ & & $\mathrm{Fe}(\mathrm{OH})_{3}(\mathrm{~s})$ & $1.0 \times 10^{-4}$ & & $\mathrm{Fe}_{3}(\mathrm{OH})_{4}^{5+}$ & $2.5 \times 10^{-7}$ \\
\hline & & & $\mathrm{Fe}(\mathrm{OH})_{3} \quad(\mathrm{~s})$ & $1.0 \times 10^{-4}$ & & & & & $\mathrm{Fe}(\mathrm{OH})_{3}(\mathrm{~s})$ & $9.9 \times 10^{-5}$ \\
\hline \multirow[t]{4}{*}{$\mathrm{HgCl}_{2}(\mathrm{Hg})$} & $10^{-4}$ & 5.5 & $\mathrm{Hg}^{2+}$ & $5.2 \times 10^{-18}$ & 7.7 & $\mathrm{Hg}^{2+}$ & $6.7 \times 10^{-18}$ & 5.5 & $\mathrm{Hg}^{2+}$ & $1.9 \times 10^{-18}$ \\
\hline & & & $\mathrm{HgCl}_{4}^{2-}$ & $5.1 \times 10^{-5}$ & & $\mathrm{HgCl}_{4}^{2-}$ & $4.8 \times 10^{-5}$ & & $\mathrm{HgCl}_{4}^{2-}$ & $7.6 \times 10^{-5}$ \\
\hline & & & $\mathrm{HgCl}_{3}^{-}$ & $4.0 \times 10^{-5}$ & & $\mathrm{HgCl}_{3}^{-}$ & $4.1 \times 10^{-5}$ & & $\mathrm{HgCl}_{3}^{-}$ & $1.9 \times 10^{-5}$ \\
\hline & & & $\mathrm{HgCl}_{2}$ & $9.3 \times 10^{-6}$ & & $\mathrm{HgCl}_{2}$ & $1.0 \times 10^{-5}$ & & $\mathrm{HgCl}_{2}$ & $5.1 \times 10^{-6}$ \\
\hline \multirow[t]{4}{*}{$\mathrm{MnCl}_{2}(\mathrm{Mn})$} & $10^{-3}$ & 5.5 & $\mathrm{Mn}^{2+}$ & $6.1 \times 10^{-4}$ & 7.7 & $\mathrm{Mn}^{2+}$ & $5.1 \times 10^{-4}$ & 5.5 & $\mathrm{Mn}^{2+}$ & $6.1 \times 10^{-4}$ \\
\hline & & & $\mathrm{MnCl}^{+}$ & $2.4 \times 10^{-4}$ & & $\mathrm{MnSO}_{4}$ & $1.9 \times 10^{-4}$ & & $\mathrm{MnCl}^{+}$ & $2.5 \times 10^{-4}$ \\
\hline & & & $\mathrm{MnCl}_{2}$ & $1.4 \times 10^{-4}$ & & $\mathrm{MnCl}^{+}$ & $1.8 \times 10^{-4}$ & & $\mathrm{MnCl}_{2}$ & $1.2 \times 10^{-4}$ \\
\hline & & & & & & $\mathrm{MnCl}_{2}$ & $9.9 \times 10^{-5}$ & & $\mathrm{MnSO}_{4}$ & $1.7 \times 10^{-5}$ \\
\hline \multirow[t]{5}{*}{$\mathrm{Pb}\left(\mathrm{NO}_{3}\right)_{2}(\mathrm{~Pb})$} & $10^{-5}$ & 5.5 & $\mathrm{~Pb}^{2+}$ & $1.7 \times 10^{-6}$ & 7.7 & $\mathrm{~Pb}^{2+}$ & $1.0 \times 10^{-7}$ & 5.5 & $\mathrm{~Pb}^{2+}$ & $1.4 \times 10^{-6}$ \\
\hline & & & $\mathrm{PbCl}^{+}$ & $5.9 \times 10^{-6}$ & & $\mathrm{PbCl}^{+}$ & $3.2 \times 10^{-7}$ & & $\mathrm{PbCl}^{+}$ & $6.5 \times 10^{-6}$ \\
\hline & & & $\mathrm{PbCl}_{2}$ & $1.9 \times 10^{-6}$ & & $\mathrm{PbSO}_{4}$ & $1.3 \times 10^{-7}$ & & $\mathrm{PbCl}_{2}$ & $1.6 \times 10^{-6}$ \\
\hline & & & $\mathrm{PbCl}_{3}^{+}$ & $5.2 \times 10^{-7}$ & & $\mathrm{~Pb}_{3}\left(\mathrm{CO}_{3}\right)_{2} \mathrm{OH}_{2}(\mathrm{~s})$ & $3.1 \times 10^{-6}$ & & $\mathrm{PbCl}_{3}^{+}$ & $3.7 \times 10^{-7}$ \\
\hline & & & & & & & & & $\mathrm{PbSO}_{4}$ & $1.5 \times 10^{-7}$ \\
\hline \multirow[t]{5}{*}{$\mathrm{UO}_{2}\left(\mathrm{CH}_{3} \mathrm{O}_{2}\right)_{2}(\mathrm{U})$} & $10^{-4}$ & 4.2 & $\mathrm{UO}_{2}^{2+}$ & $1.3 \times 10^{-7}$ & 7.7 & $\mathrm{UO}_{2}^{2+}$ & $5.6 \times 10^{-11}$ & 4.9 & $\mathrm{UO}_{2}^{2+}$ & $4.2 \times 10^{-5}$ \\
\hline & & & $\mathrm{UO}_{2}(\mathrm{OH})_{2}^{0}$ & $1.0 \times 10^{-4}$ & & $\left(\mathrm{UO}_{2}\right)\left(\mathrm{CO}_{3}\right)_{3}^{4-}$ & $1.5 \times 10^{-5}$ & & $\mathrm{UO}_{2} \mathrm{SO}_{4}$ & $6.5 \times 10^{-6}$ \\
\hline & & & & & & $\left(\mathrm{UO}_{2}\right)_{2} \mathrm{CO}_{3}(\mathrm{OH})_{3}^{-}$ & $1.5 \times 10^{-5}$ & & $\mathrm{UO}_{2} \mathrm{Cl}^{+}$ & $8.3 \times 10^{-6}$ \\
\hline & & & & & & $\left(\mathrm{UO}_{2}\right)\left(\mathrm{CO}_{3}\right)_{2}^{2-}$ & $6.6 \times 10^{-6}$ & & $\left(\mathrm{UO}_{2}\right)_{4}(\mathrm{OH})_{7}^{+}$ & $6.3 \times 10^{-6}$ \\
\hline & & & & & & $\mathrm{UO}_{2}(\mathrm{OH})_{2}(\mathrm{~s})$ & $4.7 \times 10^{-7}$ & & $\mathrm{UO}_{2} \mathrm{OH}^{+}$ & $5.2 \times 10^{-6}$ \\
\hline \multirow[t]{5}{*}{$\mathrm{ZnCl}_{2}(\mathrm{Zn})$} & $10^{-4}$ & 5.5 & $\mathrm{Zn}^{2+}$ & $7.7 \times 10^{-5}$ & 7.7 & $\mathrm{Zn}^{2+}$ & $5.2 \times 10^{-5}$ & 5.5 & $\mathrm{Zn}^{2+}$ & $7.7 \times 10^{-5}$ \\
\hline & & & $\mathrm{ZnCl}^{+}$ & $1.9 \times 10^{-5}$ & & $\mathrm{Zn}\left(\mathrm{SO}_{4}\right)$ & $1.4 \times 10^{-5}$ & & $\mathrm{ZnCl}^{+}$ & $1.8 \times 10^{-5}$ \\
\hline & & & $\mathrm{ZnCl}_{2}$ & $2.2 \times 10^{-6}$ & & $\mathrm{ZnCl}^{+}$ & $1.2 \times 10^{-5}$ & & $\mathrm{ZnCl}_{2}$ & $1.7 \times 10^{-6}$ \\
\hline & & & $\mathrm{ZnCl}_{3}^{-}$ & $1.6 \times 10^{-6}$ & & $\mathrm{ZnOHCl}$ & $8.3 \times 10^{-6}$ & & $\mathrm{Zn}\left(\mathrm{SO}_{4}\right)$ & $1.3 \times 10^{-6}$ \\
\hline & & & & & & $\mathrm{Zn}\left(\mathrm{SO}_{4}\right)_{2}^{2-}$ & $3.5 \times 10^{-6}$ & & $\mathrm{ZnCl}_{3}^{-}$ & $1.0 \times 10^{-6}$ \\
\hline
\end{tabular}

Total concentration is based on the amount of metal salt added to the medium. Only the highest total concentration common to the three bioassays is represented. Species that precipitated as solids according to the HYDRAQL calculation are marked (s).

ilar to that for $\mathrm{Pb}^{2+}$. The $\mathrm{Pb}^{2+}$ concentration was lower in the $P$. phosphoreum bioassay medium than it was in the two other bioassays (Table IV).

Each bioassay had unique metal speciation characteristics for Fe and U (Table IV). For the Microtox ${ }^{\circledR}$ bioassay, Fe occurred as soluble or precipitated hydroxide complexes in concentrations greater than that for $\mathrm{Fe}^{3+}$. Speciation was similar, but the species concentrations were greater for the photocyte bioassay However, for the P. phosphoreum bioassay most $\mathrm{Fe}$ precipitated as hydroxide complexes, the free 
ion form occurring only at a low concentration. The element $\mathrm{U}$ occurred as a hydroxide complex in the Microtox ${ }^{\circledR}$ bioassay medium in concentrations greater than that for the free ion form. In the $P$. phosphoreum bioassay medium, $\mathrm{U}$ formed soluble carbonate and precipitate hydroxide complexes, in concentrations greater than that for the free ion form. In the photocyte bioassay $U$ occurred as dissolved sulfate, chloride, or hydroxide complexes in concentrations similar to that for the free ion form. Overall, $\mathrm{UO}_{2}^{2+}$ concentration followed the ranking of $P$. phosphoreum bioassay $>$ Microtox ${ }^{\circledR}$ bioassay $>$ photocyte bioassay (Table IV).

\section{Bioassay Sensitivity}

$\mathrm{MD}_{t}$ values were different among bioassays and followed the ranking Microtox ${ }^{\circledR}<P$. phosphoreum $<$ photocyte bioassay for $\mathrm{Cr}$ and $\mathrm{Mn}$, photocyte $<P$. phosphoreum $<$ Microtox ${ }^{\circledR}$ for $\mathrm{Hg}$, and Microtox ${ }^{\circledR}<$ photocyte $<P$. phosphoreum for $\mathrm{Ag}$ and $\mathrm{Cu}$. The three bioassays had similar concentrations of free ions in the medium at the different $\mathrm{MD}_{t}$ values, a pattern usually present for the metal complexes (Fig. 3A-C). The element Ag was the exception; $\mathrm{Ag}^{+}$concentration in the medium was not similar among bioassays but increased with increasing $\mathrm{MD}_{t}$ values, a pattern also observed for $\mathrm{AgCl}_{2}^{-}$but not for the other complexes (Fig. 3D-G).

$\mathrm{MD}_{t}$ values were similar for two bioassays and greater for the third bioassay for $\mathrm{Al}, \mathrm{Cd}, \mathrm{Fe}, \mathrm{Pb}$, and $\mathrm{U}$, or lower for the third bioassay for $\mathrm{Zn}$. The Microtox ${ }^{\circledR}$ bioassay had $\mathrm{MD}_{t}$ values similar to those of the $P$. phosphoreum bioassay for $\mathrm{Al}, \mathrm{Fe}, \mathrm{Pb}$, and $\mathrm{U}$; the $P$. phosphoreum bioassay had $\mathrm{MD}_{t}$ values similar to those of the photocyte bioassay for $\mathrm{Zn}$, and the Microtox ${ }^{\circledR}$ and photocyte bioassays had similar $\mathrm{MD}_{t}$ values for $\mathrm{Cd}$. Usually, bioassays with similar $\mathrm{MD}_{t}$ values had different free-ion concentrations in the medium, whereas bioassays with different $\mathrm{MD}_{t}$ values had concentrations of free ions similar to that of one of the other bioassays (Fig. 3H-I). This pattern was not necessarily observed for the complexes (Fig. 3J-K).

\section{DISCUSSION}

The toxicity of metals was assessed using three cell-based bioluminescence assays in which a decrease of light production was used as a proxy for toxicity. In addition, chemical speciation of the metals was determined for the three common culture media used in the assays. Toxicity was observed for $\mathrm{Cd}, \mathrm{Cu}$, and $\mathrm{Hg}$ in all three bioassays, in $\mathrm{Ag}$ for the Microtox ${ }^{\circledR}$ and $P$. phosphoreum bioassays, and in $\mathrm{Al}$, $\mathrm{Cr}, \mathrm{Fe}, \mathrm{Mn}, \mathrm{Pb}, \mathrm{U}$, and $\mathrm{Zn}$ for only the Microtox ${ }^{\circledR}$ bioassay (Fig. 4). The differences observed between the bioassays reflected variations in chemical speciation and/or the biological nature of the bioassay. The relative importance of chemical speciation and biological susceptibility determines the toxicity of metals.

Catalytic Versus Noncatalytic Bioassays. Bioassays can be categorized into different groups based on how toxicants alter expression of the biological character measured by the bioassays. Catalytic bioassays respond to the alteration of enzyme activity and protein integrity, whereas noncatalytic bioassays measure alteration of antibody production and nucleic acid transcription and/or translation (Van Der Lelie et al., 1994). Capacity for long-term adaptation to the presence of a toxicant therefore indicates a noncatalytic bioassay. In this study adaptation to metals would result from the ability of cells to replicate over the course of the bioassay. The photocyte and Microtox ${ }^{\circledR}$ bioassays belong to the catalytic bioassay group. The photocyte bioassay involves eukaryotic cells that do not replicate and thus have limited adaptability to metal exposure. Similarly, the Microtox ${ }^{\circledR}$ bioassay measures acute toxicity originating from a physicochemical change because the bacteria have a slow generation time $(>2 \mathrm{~h})$ that does not allow adaptation to changes in the surrounding environment over the time of the bioassay (Ross, 1993; Bulich and Bailey, 1995; Froehner et al., 2002). The $P$. phosphoreum bioassay belongs to the noncatalytic group; the bacteria replicate and possibly adapt to changes in the surrounding environment by changes in gene and/or protein expression (Thomulka et al., 1996).

Toxicity Depends on the Metal Speciation and Biological Nature of the Cell. For $\mathrm{Cd}$ and $\mathrm{Hg}$ the chemical speciation and the decrease in light production were similar for all three bioassays despite differences in $\mathrm{pH}$ and ionic strength (I) among the media (Fig. 4). This result suggests that the chemical speciation and toxicity of those metals do not vary greatly with physicochemical conditions. Toxicity of a metal species would then depend on a combination of factors that includes the biological nature of the cells. This study showed, for instance, that for similar $\mathrm{Cd}^{2+}$ concentrations, the bacteria bioassays showed different levels of toxicity, thus indicating that a biological factor that was different between the two bioassays was involved in determining the level of toxicity. The same conclusion is reached by comparing the photocyte and Microtox ${ }^{\circledR}$ bioassays that showed different free-ion concentrations yet similar toxicity levels. The most abundant metal species present in the three media considered were chloro-complexes, which suggests they might also be toxic species. However, chloro-complexes were usually found in higher concentrations in the photocyte and Microtox ${ }^{\circledR}$ bioassays than in the P. phosphoreum bioassay that showed greater toxicity. Thus, if chloro-complexes are toxic (Bienvenue et al., 1984; Sarin et al., 2000), the cells in the three bioassays have distinct biological tolerances to these chloro-complexes.

The chemical speciation of $\mathrm{Al}$ and $\mathrm{U}$ was different among the three bioassays, as was the observed difference in toxicity (Fig. 4). For U, the hydroxide complex was the most dominant complex in the Microtox ${ }^{\circledR}$ bioassay medium, 

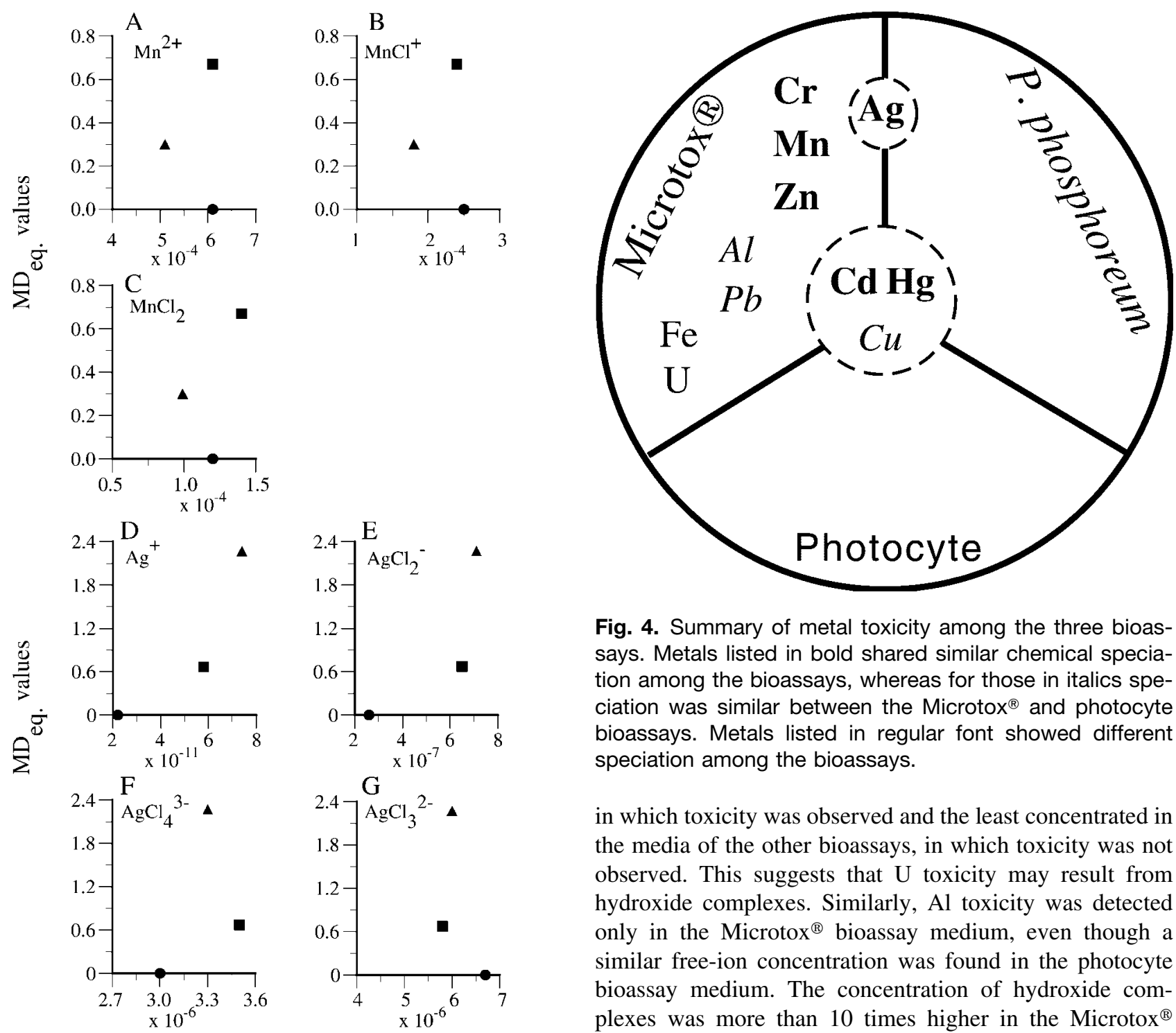

Fig. 4. Summary of metal toxicity among the three bioassays. Metals listed in bold shared similar chemical speciation among the bioassays, whereas for those in italics speciation was similar between the Microtox ${ }^{\circledR}$ and photocyte bioassays. Metals listed in regular font showed different speciation among the bioassays.

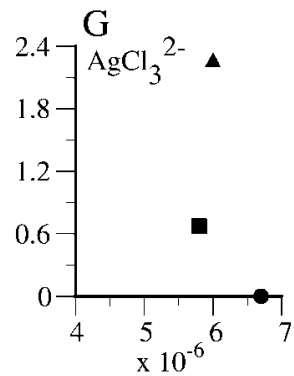

in which toxicity was observed and the least concentrated in the media of the other bioassays, in which toxicity was not observed. This suggests that $U$ toxicity may result from hydroxide complexes. Similarly, Al toxicity was detected only in the Microtox ${ }^{\circledR}$ bioassay medium, even though a similar free-ion concentration was found in the photocyte bioassay medium. The concentration of hydroxide complexes was more than 10 times higher in the Microtox ${ }^{\circledR}$ bioassay medium, suggesting that this may be the toxic form of this metal, a finding in agreement with those in previous studies (Parent et al., 1996; Simkiss and Taylor, 2001).

The element Ag was toxic in the Microtox ${ }^{\circledR}$ and $P$. phosphoreum bioassays but not in the photocyte bioassay, despite similar metal speciation for all three media. The lack of toxicity in the photocyte bioassay may be related to differences in susceptibility of the cells to metals as well as to differences in ionic strength among the media. Toxicity in the bioassays was correlated with the concentrations of $\mathrm{Ag}^{+}$ and $\mathrm{AgCl}_{2}^{-}$, suggesting that these metal species are toxic. The concentration of the metal complex $\mathrm{AgCl}_{3}^{2-}$ in the three assays was highest in the photocyte bioassay, supporting that this species is the least toxic. In addition, Ag elicited a

Fig. 3. Toxicity $\left(M D_{t}\right.$ values) of $(A-C) M n$, (D-G) $A g$, and $(\mathrm{H}-\mathrm{K}) \mathrm{Cd}$ for the three bioassays as a function of concentration of each metal species (symbols legend: $\mathbf{a}$, Microtox $^{\circledR}$ assay; $\boldsymbol{\Lambda}, P$. phosphoreum assay; •: photocyte assay). 
toxic response only in bioassays using bacteria, suggesting that with this metal there are different mechanisms of toxicity for prokaryotic and metazoan cells.

The elements $\mathrm{Cr}, \mathrm{Mn}$, and $\mathrm{Zn}$ showed similar chemical speciation for the three media, yet toxicity was observed only with the Microtox ${ }^{\circledR}$ bioassay. This was not an artifactual result, because in this study the greatest free-ion concentration found to induce toxicity in the Microtox ${ }^{\circledR}$ bioassay was on the same order of magnitude as the 15-min $\mathrm{EC}_{50}$ of the bioassay (McCloskey et al., 1996). This result thus emphasizes that the biological nature of the cell and/or physicochemical parameters of the medium should also be considered to properly assess the toxic potential of metal species.

The element $\mathrm{Cu}$ was toxic at $10^{-4} \mathrm{M}$ with both bacterialbased bioassays but not with the photocyte bioassay. The Microtox ${ }^{\circledR}$ and photocyte bioassays had the same metal speciation for $\mathrm{Cu}$. Thus, the difference in toxicity response may result from differences in biological processes leading to toxicity or from the difference between the two media in ionic strength, assuming that biological processes can be affected by the load of salt in the medium (Hall and Anderson, 1995; Hall et al., 1995a; 1995b; Cook et al., 2000). The $P$. phosphoreum bioassay also exhibited toxicity despite a different chemical speciation than the Microtox ${ }^{\circledR}$ bioassay and a low concentration of free $\mathrm{Cu}$. Yet in this case, thermodynamic calculations predicted $\mathrm{Cu}$ precipitation under a hydroxide form. As precipitate was not observed over the time frame of the experiment, it is difficult to establish whether toxicity observed in this bioassay was from free ions and/or cupric hydroxides.

Thermodynamic calculations for equilibrium conditions at $25^{\circ} \mathrm{C}$ predicted $\mathrm{Fe}$ precipitation as a ferric hydroxide in all three bioassays. However, no precipitation was observed during the experiment, and therefore, in the absence of precipitate, Fe hydroxide complexes dominated the speciation in all three assays. Only the Microtox bioassay showed evidence of toxicity, suggesting that Fe hydroxides may be toxic species.

Toxicity Assessment Using the Microtox ${ }^{\circledR}$ Bioassay Has Poor Metal Specificity. The Microtox ${ }^{\circledR}$ and P. phosphoreum bioassays use two strains of the same bacterial species, Photobacterium phosphoreum. Strain 11177, used in the Microtox ${ }^{\circledR}$ bioassay, is highly sensitive to contaminants (http://www.azurenv.com) including metals (Codina et al., 1993; Ghosh et al., 1996). Indeed, the toxicity response of the $P$. phosphoreum Microtox ${ }^{\circledR}$ bioassay to $\mathrm{Cr}$, Mn, and $\mathrm{Zn}$ contrasted with the lack of effect of the same metals with similar speciation on the wild strain of $P$. phosphoreum. In the present study, the Microtox ${ }^{\circledR}$ bioassay exhibited poor specificity to different metals, consistent with previous findings (Ross, 1993). According to the Microtox ${ }^{\circledR}$ bioassay results, all metals were toxic at high concentrations $\left(10^{-4}\right.$ and $10^{-3} \mathrm{M}$ ), whereas only $\mathrm{Ag}, \mathrm{Al}, \mathrm{Hg}, \mathrm{U}$, and $\mathrm{Zn}$ were toxic at lower concentrations. In contrast, for the P. phos- phoreum bioassay, the wild strain showed decreased bioluminescence only to $\mathrm{Ag}, \mathrm{Cd}, \mathrm{Cu}$, and $\mathrm{Hg}$. Fe plays an important role in the regulation of growth and bioluminescence in P. phosphoreum (Haygood and Nealson, 1984, 1985a, 1985b). This element maintains a delicate balance between promoting growth, which has a stimulatory effect on light production, and repressing bioluminescence. Accordingly, the $P$. phosphoreum bioassay showed that bioluminescence and cell concentration decreased for lower $\mathrm{Fe}$ concentrations $\left(10^{-8}-10^{-6} \mathrm{M}\right)$ and increased for higher concentrations $\left(10^{-5}-10^{-4} \mathrm{M}\right)$. This pattern was not observed for the Microtox ${ }^{\circledR}$ bioassay strain. In fact, the effect of Fe was the opposite of that on the wild-type strain, with bioluminescence decreasing for higher concentrations of the metal.

Toxicity Depends on the Cell Concentration of the Bacteria. The $P$. phosphoreum bioassay showed that metals affected bacterial bioluminescence as well as growth. For $\mathrm{Ag}$, the decrease in bioluminescence was simultaneous with the decrease in cell concentration. However, in general, bioluminescence was a more sensitive indicator than growth and decreased prior to the decrease in cell concentration, as observed for $\mathrm{Cd}, \mathrm{Cu}, \mathrm{Hg}$, and $\mathrm{Zn}$. The relation between cell concentration and bioluminescence in $P$. phosphoreum is supported by an elaborate physiological coupling (Hastings and Nealson, 1977; Haygood and Nealson, 1985b) that suggests consideration of both parameters simultaneously. Bacteria could indeed reach optimal bioluminescence and growth in responses to changes in the medium if allowed sufficient time.

This study showed that on exposure to $\mathrm{Al}$, bioluminescence decreased throughout the 2-h duration of the Microtox ${ }^{\circledR}$ bioassay, corresponding to the cell generation time (Bulich and Bailey, 1995; Bulich and Huynh, 1995). For the $P$. phosphoreum bioassay, bioluminescence decreased and cell concentration increased for the first $2 \mathrm{~h}$ of metal exposure; however, the trend was reversed after $3 \mathrm{~h}$ of exposure, with an increase in bioluminescence and decrease in cell concentration, suggesting reduced Al toxicity for chronic exposure. Such variation of effects with time of exposure (viz., cell division rate) was also observed for $\mathrm{Pb}, \mathrm{U}$, and $\mathrm{Zn}$. The use of long-term exposure to contaminants has been suggested as a way to better assess toxicity when using bacteria (Dillon, 1993; Thomulka et al., 1993; Newman and McCloskey, 1996; Thomulka et al., 1996; Backhaus et al., 1997; Froehner et al., 2000). Such a long-term exposure Microtox ${ }^{\circledR}$-based bioassay has been developed, the Microtox ${ }^{\circledR}$ Chronic Toxicity test (Bulich and Bailey, 1995; Bulich and Huynh, 1995; Johnson, 1998; see also http://www. azurenv.com); the disadvantage of this bioassay is that it involves more time, expense, and specific skills for microbial work than the original Microtox ${ }^{\circledR}$ Acute Toxicity test.

The Microtox ${ }^{\circledR}$ Bioassay Can Overestimate Toxicity of Marine Samples. Free-metal-ion concentration can be compared for various media, including a freshwater medium 
(McCloskey et al., 1996), the Microtox ${ }^{\circledR}$ bioassay medium (Newman and McCloskey, 1996), and an artificial seawater medium (the latter two used in this study). The proportion of free ions in the medium (ratio of free-ion concentration to total unspeciated concentration) followed the sequence: freshwater $>$ Microtox ${ }^{\circledR}>$ artificial seawater. For most metals free-metal-ion concentration was about 1-2 times greater in freshwater than in the Microtox ${ }^{\circledR}$ bioassay medium; but it was, 10 times greater for $\mathrm{Cd}$ and $10^{8}$ times greater for $\mathrm{Hg}$. The free-metal-ion concentration of most metals was about 4 times greater in the Microtox ${ }^{\circledR}$ bioassay medium than in artificial seawater, except it was 40 times greater for $\mathrm{Fe}, 100$ times greater for $\mathrm{U}$, and 200 times greater for Al. Free-metal-ion concentration values calculated in this study for the Microtox ${ }^{\circledR}$ bioassay were similar to (only about 1.2 times higher) previous values for the same metals and bioassay (Newman and McCloskey, 1996), indicating that the speciation calculations were accurate. Chemical speciation of metals in solution is affected by ionic strength and other physicochemical parameters like salinity, $\mathrm{pH}$, and calcium concentration of the medium (Brezonik et al., 1991; Ho et al., 1999; Cook et al., 2000). Therefore, assuming that toxicity is related to metal speciation, a toxicity assessment of a freshwater or marine sample might be biased when using the Microtox ${ }^{\circledR}$ bioassay, which has a NaCl-based medium (Villaescusa et al., 1996). This bioassay is known to overestimate the toxicity of metals more than do seawater-based nonmicrobial bioassays (Becerro et al., 1995; Ghosh et al., 1996). This could be because of the difference in speciation (i.e., fewer complexes in the Microtox ${ }^{\circledR}$ bioassay medium), but it also could be a result of the inherent sensitivity of Microtox ${ }^{\circledR}$ cells to metals. In addition, the Microtox ${ }^{\circledR}$ bioassay underestimates the toxicity of metals in freshwater relative to freshwaterbased nonmicrobial bioassays (Ankley et al., 1990; George et al., 1995; Pardos et al., 1999; Radix et al., 2000). This also could be because of the difference in speciation (i.e., fewer complexes in freshwater).

Metal toxicity depends on multiple factors that cannot be integrated into a single bioassay, so it is generally accepted that a battery of assays should be used to better assess metal effects and cover the array of toxicity factors (Codina et al., 1993; Cronin and Dearden, 1993; Ross, 1993; Thomulka et al., 1996). Because of speciation issues as well as the inherent sensitivity of the Microtox ${ }^{\circledR}$ bioassay strain, it appears that it is not appropriate to use the Microtox ${ }^{\circledR}$ bioassay for assessing natural conditions of contamination and toxicity for metazoans (Dutka and Kwan, 1981; Radix et al., 2000).

The Photocyte Bioassay, Which Belongs to the Catalytic Group, Allows Assessment of the Physiological Effect of Metals Under Realistic Marine Conditions. The photocyte bioassay uses isolated light-producing cells from an osmoconforming invertebrate. Seawater is therefore the best medium in which photocytes can be maintained (Deheyn et al., 2000a). The artificial seawater medium used in this study approaches the salt composition and physicochemical properties of natural seawater, which has an average ionic strength of 0.611 ( $0.511-0.650$ range; 0.61 in the bioassay; Turner et al., 1981; Atkinson and Bingman, 1997).

Of the 11 metals tested, the photocyte bioassay showed toxicity for $\mathrm{Cd}, \mathrm{Cu}$, and $\mathrm{Hg}$. These metals are also known to affect sea urchin fertilization and embryonic development at comparable concentrations (Kennish, 1997). The elements $\mathrm{Cr}, \mathrm{Zn}, \mathrm{Al}$, and Fe inhibit sea urchin embryonic development (Pagano et al., 1996; Kennish, 1997) at concentrations that had no effect on photocytes. As the echinoderm embryonic development bioassay belongs to the noncatalytic group of toxicity assays, the photocyte-embryonic development toxicity discrepancy does not necessarily indicate the photocyte bioassay is the least sensitive; rather, it implies a difference in sensitivity for those metals between the pre- and post-metamorphic stages of development in echinoderms. Unfortunately, there are no published metal toxicity data for postmetamorphic echinoderms to allow appropriate comparison with the photocyte bioassay.

Metals are known to affect bioluminescence capacity in eukaryotic organisms (Okamoto et al., 1999; Deheyn et al., 2000b; Sudhaharan and Reddy, 2000), yet bioluminescence has been used as a proxy for metal toxicity only for dinoflagellates (Lapota et al., 1993; Heimann et al., 2002) and brittlestars (present study). The photocyte bioassay was more than 30 times less sensitive to $\mathrm{Cd}$ and $\mathrm{Cu}$ than the bioluminescence bioassay using the dinoflagellate Pyrocystis lunula, yet the two bioassays showed similar sensitivity to $\mathrm{Pb}$ (Heimann et al., 2002). In contrast, the photocyte bioassay showed sensitivity to $\mathrm{Cu}$ and $\mathrm{Zn}$ similar to that of the bioluminescence bioassay when using the dinoflagellate Lingulodinium polyedrum (formerly Gonyaulax polyedra; Lapota et al., 1993). Therefore, the photocyte bioassay has a sensitivity range comparable to that of other bioluminescence-based bioassays using eukaryotic cells.

\section{CONCLUSIONS}

The metal speciation in the original environment of the sample must be preserved in the bioassay to avoid over- or underestimation of toxicity. The use of specific strains of microorganisms is useful to detect low levels of a given element potentially bioavailable in the environment, but toxicity established by a strain may not extrapolate to toxicity for other biological systems.

\footnotetext{
We thank N. Schulte-Pelkum and B. Marchione for valuable help in performing the bioassays and L. Blankenship for statistical advice. The wild strain of Photobacterium phosphoreum was kindly provided by M. Haygood. We thank M. Haygood, B. Tebo, and members of their research group for technical assistance.
} 


\section{REFERENCES}

Ankley GT, Peterson GS, Amato JR, Jenson JJ. 1990. Evaluation of sucrose as an alternative to sodium chloride in the Microtox assay-comparison to fish and cladoceran tests with freshwater effluents. Environ Toxicol Chem 9:1305-1310.

Atay NZ, Robinson BH. 1999. Kinetic studies of metal ion complexation in glycerol-in-oil microemulsions. Langmuir 15:5056-5064.

Atay NZ, Varnali T. 2000. A computational study on metal ion/ PADA complexation in water and in glycerol. Theochem-J Mol Struct 507:137-143.

Atkinson MJ, Bingman C. 1997. Elemental composition of commercial seasalts. J Aquaric Aquat Sci 8:39-43.

AZUR Environmental Limited. 1992. User manuals. Workingham, UK: AZUR Environmental.

Backhaus T, Froehner K, Altenburger R, Grimme LH. 1997. Toxicity testing with Vibrio fischeri: A comparison between the long term $(24 \mathrm{~h})$ and the short term $(30 \mathrm{~min})$ bioassay. Chemosphere 35:2925-2938.

Becerro MA, Uriz MJ, Turon X. 1995. Measuring toxicity in marine environments: critical appraisal of three commonly used methods. Experientia 51:414-418.

Bienvenue E, Boudou A, Desmazes JP, Gavach C, Georgescauld D, Sandeaux J, Seta P. 1984. Transport of mercury compounds across bimolecular lipid membranes: effect of lipid composition, $\mathrm{pH}$ and chloride concentration. Chem-Biochem Interact 48:91101.

Brezonik Pl, King SO, Mach CE. 1991. The influence of water chemistry on trace metal bioavailibility and toxicity to aquatic organisms. In: Newman MC, McIntosh AW, editors. Metal ecotoxicology: concepts \& applications. Chelsea, MI: Lewis Publishers. p 1-31.

Bulich AA, Bailey G. 1995. Environmental toxicity assessment using luminescent bacteria. In: Richardson M, editor. Environmental toxicology assessment. London: Taylor and Francis. p $29-40$.

Bulich AA, Huynh H. 1995. Measuring chronic toxicity using luminescent bacteria. Can Tech Rep Fish Aquat Sci 2050:23.

Bulich AA, Isenberg DL. 1980. Use of the luminescent bacterial system for the rapid assessment of aquatic toxicity. Adv Instrum 35:35-39.

Byrne RH, Kump LR, Cantrell KJ. 1988. The influence of temperature and $\mathrm{pH}$ on trace metal speciation in seawater. Mar Chem 25:163-181.

Campbell PGC, Tessier A. 1996. Ecotoxicology of metals in the aquatic environment: geochemical aspects. In: Newman MC, Jagoe $\mathrm{CH}$, editors. Ecotoxicology. A hierarchical treatment. Boca Raton, FL: CRC Press. p 11-58.

Clark RB. 1997. Marine pollution. Oxford, UK: Oxford University Press. $161 \mathrm{p}$.

Codina JC, Perez-Garcia A, Romero P, De Vicente A. 1993. A comparison of microbial bioassays for the detection of metal toxicity. Arch Environ Contam toxicol 25:250-254.

Cook SV, Chu A, Goodman RH. 2000. Influence of salinity on
Vibrio fischeri and lux-modified Pseudomonas fluorescens toxicity bioassays. Environ Toxicol Chem 19:2474-2477.

Costan G, Bermingham N, Blaise C, Ferard JF. 1993. Potential Ecotoxic Effects Probe (Peep)—a novel index to assess and compare the toxic potential of industrial effluents. Environ Toxic Water Qual 8:115-140.

Cronin MTD, Dearden JC. 1993. The comparative toxicology of the Microtox test. In: Richardson ML, editor. Ecotoxicology monitoring. New York: VCH Verlagsgesellschaft. p 213-223.

Crosby DG. 1998. Environmental toxicology and chemistry. Bricks JW, editor. New York: Oxford University Press. 336 p.

Danilov VS, Ismailov AD, Baranova NA. 1985. The inhibition of bacterial bioluminescence by xenobiotics. Xenobiotica 15:271276.

Deheyn D, Mallefet J, Jangoux M. 2000a. Cytological changes during bioluminescence production in dissociated photocytes from the ophiuroid Amphipholis squamata (Echinodermata). Cell Tiss Res 299:115-128.

Deheyn D, Jangoux M, Warnau M. 2000b. Alteration of bioluminescence in Amphipholis squamata (Ophiuroidea: Echinodermata) by heavy metals contamination: a field study. Sci Tot Environ 247:41-49.

Dillon TM. 1993. Developing chronic sublethal sediment bioassays: a challenge to the scientific community. In: Richardson ML, editor. Ecotoxicology monitoring. New York: VCH Verlagsgesellschaft. p 623-639.

Dizer H, Wittekindt E, Fischer B, Hansen PD. 2002. The cytotoxic and genotoxic potential of surface water and wastewater effluents as determined by bioluminescence, umu-assays and selected biomarkers. Chemosphere 46:225-233.

Dutka BJ, Kwan KK. 1981. Comparison of three microbial toxicity screening tests with the Microtox test. Bull Environ Contam Toxicol 27:753-757.

Froehner K, Backhaus T, Grimme LH. 2000. Bioassays with Vibrio fischeri for the assessment of delayed toxicity. Chemosphere 40:821-828.

Froehner K, Meyer W, Grimme LH. 2002. Time-dependent toxicity in the long-term inhibition assay with Vibrio fischeri. Chemosphere 46:987-997.

Gellert G, Stommel A, Trujillano AB. 1999. Development of an optimal bacterial medium based on the growth inhibition assay with Vibrio fischeri. Chemosphere 39:467-476.

George DB, Berk SG, Adams VD, Ting RS, Roberts RO, Parks LH, Lott RC. 1995. Toxicity of Alum sludge extracts to a freshwater alga, protozoan, fish, and marine bacterium. Arch Environ Contam Toxicol 29:149-158.

Ghosh SK, Doctor PB, Kulkarni PK. 1996. Toxicity of zinc in three microbial test systems. Environ Toxicol Water Qual 11: 13-19.

Hall LW, Anderson RD. 1995. The influence of salinity on the toxicity of various classes of chemicals to aquatic biota. Crit Rev Toxicol 25:281-346.

Hall LW, Ziegenfuss MC, Anderson RD, Lewis BL. 1995a. The effect of salinity on the acute toxicity of total and free cadmium to a Chesapeake Bay copepod and fish. Mar Pollut Bull 30:376384. 
Hall LW, Ziegenfuss MC, Anderson RD, Tierney DP. 1995b. The influence of salinity on the chronic toxicity of atrazine to an estuarine copepod: Implications for development of an estuarine chronic criterion. Arch Environ Contam Toxicol 28:344-348.

Hastings WJ, Nealson KH. 1977. Bacterial bioluminescence. Ann Rev Microbiol 31:549-595.

Haygood MG, Nealson KH. 1984. Effects of iron on bacterial growth and luminescence: ecological implications. In: Klug MJ, Reddy CA, editors. Current perspectives in microbial ecology. Washington DC: American Society for Microbiology. p 56-61.

Haygood MG, Nealson KH. 1985a. Mechanisms of iron regulation of luminescence in Vibrio fischeri. J Bacteriol 162:209-216.

Haygood MG, Nealson KH. 1985b. The effect of iron on the growth and luminescence of the symbiotic bacterium Vibrio fischeri. Symbiosis 1:39-51.

Heimann K, Matuszewski JM, Klerks PL. 2002. Effects of metals and organic contaminants on the recovery of bioluminescence in the marine dinoflagellate Pyrocystis lunula (Dinophyceae). J Phycol 38:482-492.

Ho KT, Kuhn A, Pelletier MC, Hendricks TL, Helmstetter A. 1999. $\mathrm{pH}$ dependent toxicity of five metals to three marine organisms. Environ Toxicol 14:235-240.

Hollis RP, Killham K, Glover LA. 2000. Design and application of a biosensor for monitoring toxicity of compounds to eukaryotes. Appl Environ Microbiol 66:1676-1679.

Johnson BT. 1998. Microtox ${ }^{\circledR}$ toxicity test systems-New developments and applications. In: Wells PG, Lee K, Blaise C, editors. Microscale testing in aquatic toxicology: Advances, techniques, and practice. Boca Raton, Florida: CRC Press. p 201-218.

Kennish MJ. 1997. Practical handbook of estuarine and marine pollution. Kennish MJ, Lutz PL, editors. Boca Raton: CRC Press. 524 p.

Kudryasheva N, Kratasyuk V, Esimbekova E, Vetrova E, Nemtseva E, Kudinova I. 1998. Development of bioluminescent bioindicators for analysis of environmental pollution. Field Anal Chem Technol 2:277-280.

Kuroshima R, Kimura S, Date K, Yamamoto Y. 1993. Kinetic analysis of cadmium toxicity to red sea bream, Pagrus major. Ecotoxicol Environ Saf 25:300-314.

Lapota D, Moskowitz GJ, Rosenberger DE, Grovhoug JGG. 1993. The use of stimulable bioluminescence from marine dinoflagellates as a means of detecting toxicity in the marine environment. In: Gorsuch JW, Dwyer FJ, Ingersoll CG, La Point TW, editors. Environmental toxicology and risk assessment. Philadelphia: American Society for Testing and Materials. p 3-18.

Mallefet J, Vanhoutte P, Baguet F. 1992. Study of Amphipholis squamata luminescence. In: Scalera-Liaci L, Canicatti C, editors. Echinoderm research. Rotterdam: Balkema, A. A. p 125130.

Martell AE, Smith RM. 1974. Critical stability constants. New York: Plenum Press.

Martell AE, Smith RM, Motekaitis RJ. 1993. NIST critically selected stability constants for metal complexes database, NIST Standard Reference Data (electronic). Texas A\&M University: College Station, TX.

McCloskey JT, Newman MC, Clark SB. 1996. Predicting the relative toxicity of metal ions using ion characteristics: Microtox bioluminescence assay. Environ Toxicol Chem 15:17301737.

Millero FJ, Hawke DJ. 1992. Ionic interactions of divalent metals in natural waters. Mar Chem 40:19-48.

Millero FJ, Schreiber DR. 1982. Use of the ion pairing model to estimate activity coefficients of the ionic components of natural waters. Am J Sci 282:1508-1540.

Morel FMM, Hering JG. 1993. Principles and applications of aquatic chemistry. New York: John Wiley \& Sons. 588 p.

Morin JG. 1983. Coastal bioluminescence: patterns and functions. Bull Mar Sci 33:787-817.

Motulsky H. 1995. Intuitive biostatistics. New York: Oxford University Press. 386 p.

Nealson KH. 1978. Isolation, identification, and purification of luminous bacteria. In: DeLuca MA, editor. Methods in enzymology. San Francisco: Academic Press. p 153-166.

Newman MC, McCloskey JT. 1996. Predicting relative toxicity and interactions of divalent metal ions: Microtox bioluminescence assay. Environ Toxicol Chem 15:275-281.

Okamoto OK, Shao LM, Hastings JW, Colepicolo P. 1999. Acute and chronic effects of toxic metals on viability, encystment and bioluminescence in the dinoflagellate Gonyaulax polyedra. Comp Biochem Physiol C 123:75-83.

Pagano G, His E, Beiras R, DeBiase A, Korkina LG, Iaccarino M, Oral R, Quiniou F, Warnau M, Trieff NM. 1996. Cytogenetic, developmental, and biochemical effects of aluminum, iron, and their mixture in sea urchins and mussels. Arch Environ Contam Toxicol 31:466-474.

Papelis C, Hayes KF, Leckie JO. 1988. HYDRAQL: A program for the computation of chemical equilibrium composition of aqueous batch systems including surface-complexation modeling of ion adsorption at the oxide/solution interface. Stanford, CA: Stanford University. Report No. 306.130 p.

Pardos M, Benninghoff C, Gueguen C, Thomas R, Dobrowolski J, Dominik J. 1999. Acute toxicity assessment of Polish (waste) water with a microplate-based Hydra attenuata assay: A comparison with the Microtox ${ }^{\circledR}$ test. Sci Tot Environ:141-148.

Parent L, Twiss MR, Campbell PGC. 1996. Influences of natural dissolved organic matter on the interaction of aluminum with the microalga Chlorella: A test of the free-ion model of trace metal toxicity. Environ Sci Technol 30:1713-1720.

Porter KG, Feig YS. 1980. The use of 4'6 di amidino-2-phenyl indole for identifying and counting aquatic micro flora. Limnol Oceanogr 25:943-948.

Radix P, Leonard M, Papantoniou C, Roman G, Saouter E, Gallotti-Schmitt S, Thiebaud H, Vasseur P. 2000. Comparison of four chronic toxicity tests using algae, bacteria, and invertebrates assessed with sixteen chemicals. Ecotoxicol Environ Saf 47:186-194.

Ramamoorthy S, Kushner DJ. 1975. Binding of mercuric and other heavy metal ions by microbial growth media. Microb Ecol 2:162-176.

Richardson ML. 1993. Epilogue. In: Richardson ML, editor. Ecotoxicology monitoring. New York: VCH Verlagsgesellschaft. $p$ 335-343. 
Ross P. 1993. The use of bacterial luminescence systems in aquatic toxicity testing. In: Richardson ML, editor. Ecotoxicology monitoring. New York: VCH Verlagsgesellschaft. p 185-195.

Sarin C, Hall JM, Cotter-Howells J, Killham K, Cresser MS. 2000. Influence of complexation with chloride on the responses of a lux-marked bacteria bioassay to cadmium, copper, lead, and mercury. Environ Toxicol Chem 19:259-264.

Simkiss K, Taylor MG. 2001. Trace element speciation at cell membranes: aqueous, solid and lipid phase effects. J Environ Monit 3:15-21.

Slob W. 2002. Dose-response modeling of continuous endpoints. Toxicol Sci 66:298-312.

Smith DC, Steward GF, Long RA, Azam F. 1995. Bacterial mediation of carbon fluxes during a diatom bloom in a mesocosm. Deep-Sea Res II 42:75-97.

Stumm W, Morgan JJ. 1995. Aquatic chemistry: chemical equilibria and rates in natural waters. New York: John Wiley \& Sons. $1022 \mathrm{p}$.

Sudhaharan T, Reddy AR. 2000. Metal ion mediated inhibition of firefly bioluminescence: a possibility via a quaternary complex. Ind J Biochem Biophys 37:256-267.
Thomulka KW, Abbas CG, Young DA, Lange JH. 1996. Evaluating median effective concentrations of chemicals with bioluminescent bacteria. Bull Environ Contam Toxicol 56:446-452.

Thomulka KW, McGee DJ, Lange JH. 1993. Detection of biohazardous materials in water by measuring bioluminescence reduction with the marine organism Vibrio harveyi. J Environ Sci Health A 28:2153-2166.

Turner DR, Whitfield M, Dickson AG. 1981. The equilibrium speciation of dissolved components in freshwater and seawater at $25^{\circ} \mathrm{C}$ and $1 \mathrm{~atm}$ pressure. $45: 855-881$.

Van Der Lelie D, Corbisier P, Baeyens W, Wuertz S, Diels L, Mergeay M. 1994. The use of biosensors for environmental monitoring. Res Microbiol 145:67-74.

Villaescusa I, Martinez M, Pilar M, Murat JC, Hosta C. 1996. Toxicity of cadmium species on luminescent bacteria. Fresenius J Anal Chem 354:566-570.

Wood KV, Gruber MG. 1996. Transduction in microbial biosensors using multiplexed bioluminescence. Biosens Bioelectron 11:207-214.

Zar JH. 1996. Biostatistical analysis. Upper Saddle River, NJ: Prentice-Hall. 662 p. 